\title{
Functional Evaluations in the Monitoring of the River Ecosystem Processes: The Adige River as a Case Study
}

\author{
M.G. Braioni ${ }^{*, 1}$, G. Salmoiraghi ${ }^{2}$, F. Bracco ${ }^{1}$, M. Villani $^{1}$, A. Braioni ${ }^{3}$, and L. Girelli ${ }^{3}$ \\ ${ }^{1}$ Department of Biology, University of Padova, Via U. Bassi 58/B Italy; ${ }^{2}$ Department of \\ Evolutionary Biology, University of Bologna, Via Selmi 3 Italy; ${ }^{3}$ Architect, vc. Ponte \\ Nuovo 9, 37126 Verona, Italy
}

Received August 3, 2001; Revised December 16, 2001; Accepted January 2, 2002; Published March 12, 2002

\begin{abstract}
A model of analysis and environmental evaluation was applied to 11 stretches of the Adige River, where an innovative procedure was carried out to interpret ecological results. Within each stretch, the most suitable methods were used to assess the quality and processes of flood plains, banks, water column, bed, and interstitial environment. Indices were applied to evaluate the wild state and ecological quality of the banks (wild state index, buffer strip index) and the landscape quality of wide areas of the fluvial corridor (environmental landscape index). The biotic components (i.e., macrozoobenthos, phytoplankton and zooplankton, interstitial hyporheic fauna, vegetation in the riparian areas) were analysed by both quantitative and functional methods (as productivity, litter processing and colonisation). The results achieved were then translated into five classes of functional evaluation. These qualitative assessments have thus preserved a high level of precision and sensitivity in quantifying both the quality of the environmental conditions and the integrity of the ecosystem processes. Read together with urban planning data, they indicate what actions are needed to restore and rehabilitate the Adige River corridor.
\end{abstract}

KEY WORDS: river basin planning, river ecological processes, assessment methods, banks ecological indices, environmental landscape index, wild state index, buffer strip index

DOMAINS: ecosystems management, environmental management and policy, environmental monitoring, freshwater systems, plant sciences

\section{INTRODUCTION}

Four factors - the river continuum concept[1,2], nutrient spiralling[3], river mosaic[4,5], and a multidimensional approach to the river ecosystem[6,7,8] - have favoured the development of methods appropriate for measuring functional processes. 


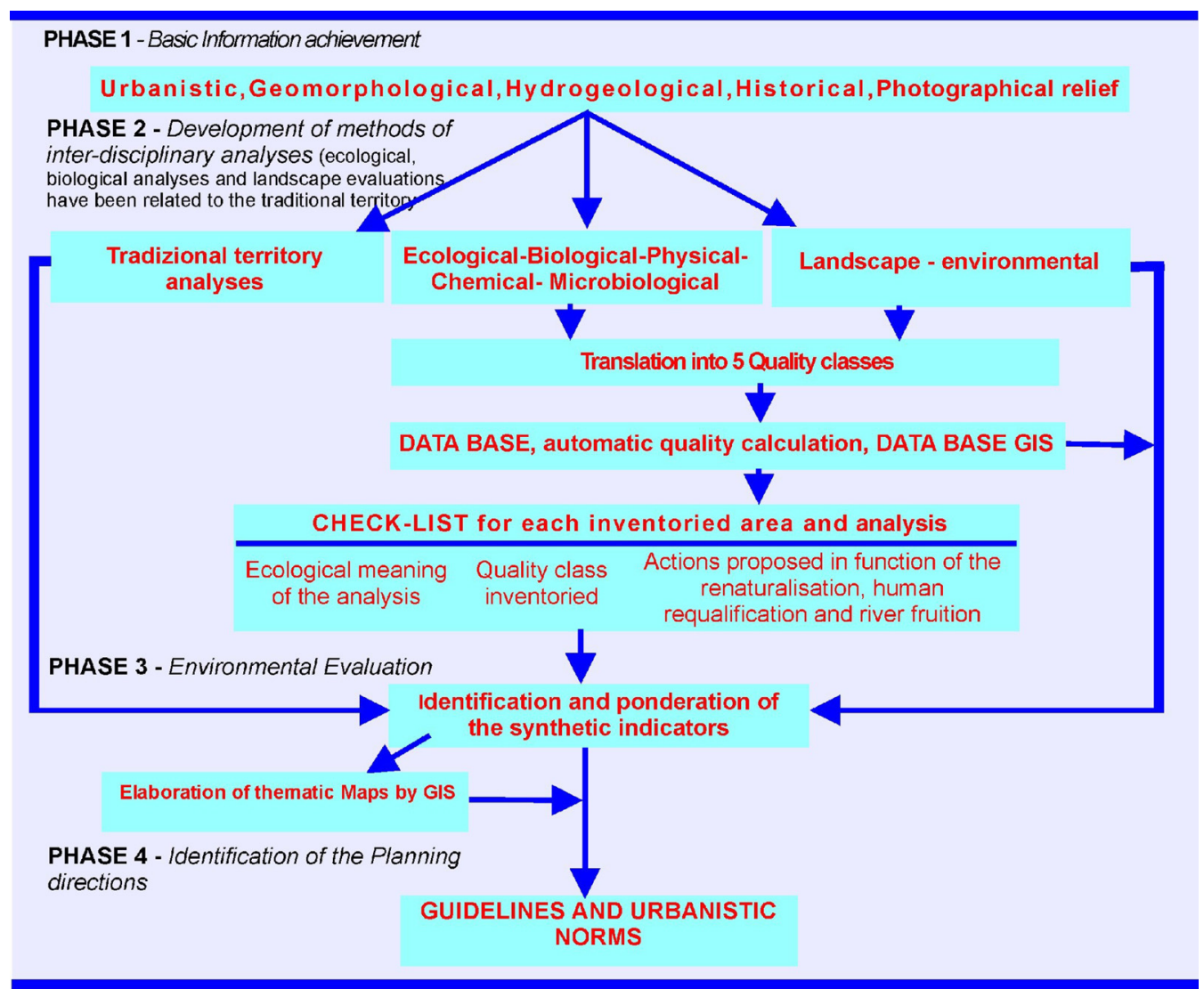

FIGURE 1. Scheme of the analysis and environmental evaluation (modified from [10]).

European Directive 2000/60[9] established a framework for community action in the field of water policy that has the following objectives: human development compatible with restoration, environmental safeguards, and defence from flood as well as dryness. The instrument for taking such action is the River Basin Management Plan, which outlines two essential steps: the ecological data of the river system must be read in the same context of those traditionally analysed by the Urban Planning experts, and all the "hydro-morphological and biological elements" reported in Annex V of the Water Framework Directive must present standardised monitoring procedures. It is therefore important to develop methods for monitoring the quality of ecosystem compartments so far neglected (banks and riparian areas, for example) and to define procedures for monitoring the quantitative processes of the fluvial ecosystem.

To achieve these goals, several indices for evaluating the quality of banks and riparian areas were applied within the model of analysis and environmental evaluation (Fig. 1) tested on 11 sample areas of the Adige River corridor. The procedures for translating the results of the quantitative methods into functional evaluations have also been defined. The sensitivity and the specificity of the results on the components and compartments of the analysed ecosystems have been granted. At the same time, the data were implemented together with those of the other disciplines involved in the layout of the Basin Plan. The definition of the Quality, Degradation and Risks Map is an example of actuation of an integrated reading of all the data of the river and fluvial corridor examined. The Planning Use Map, which is not reported on this paper[10,11], is an example of the norms of planning and management that can be derived from an integrated reading of the territory data. 


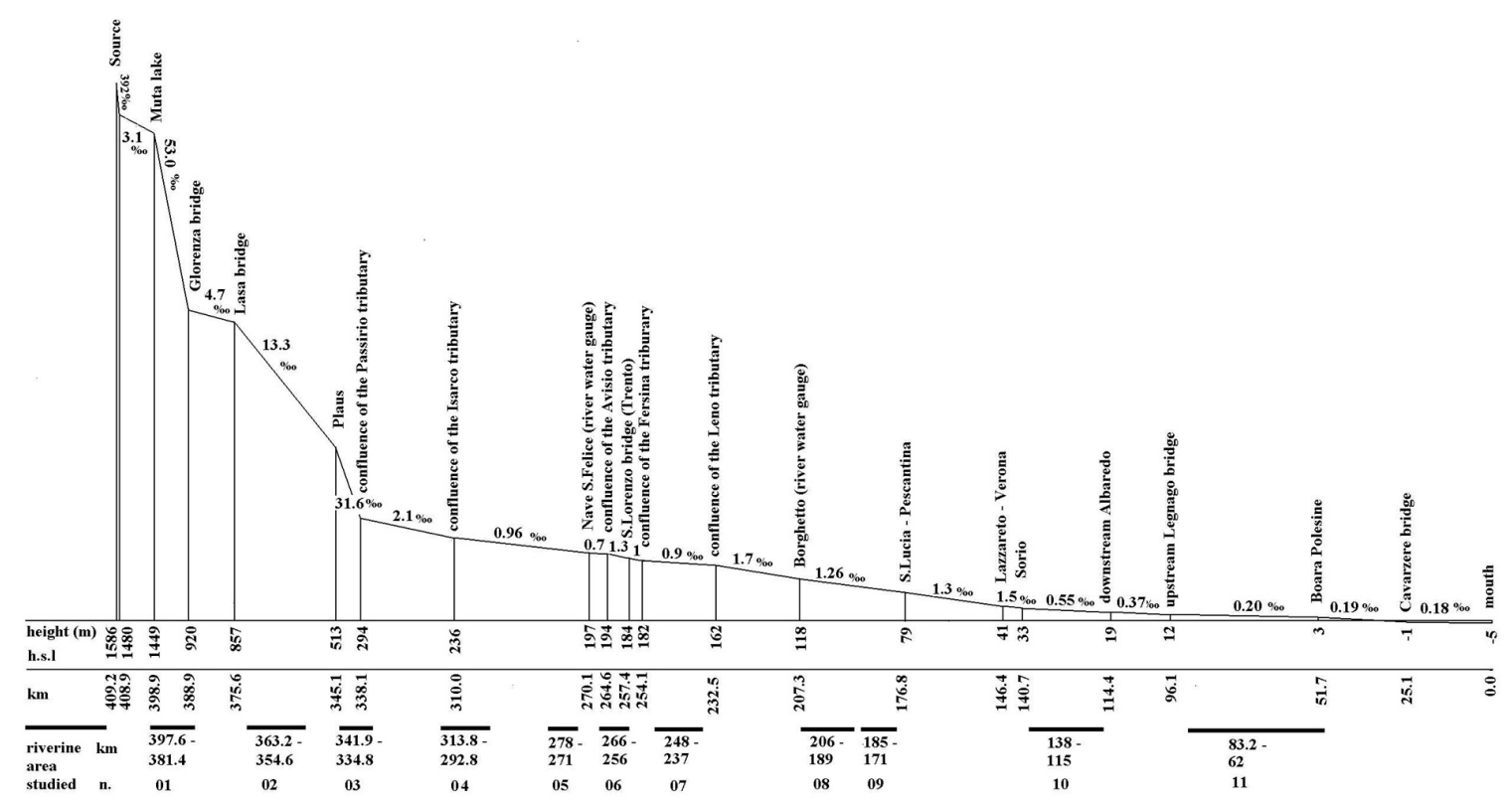

FIGURE 2. The Adige River. Location of the 11 areas of the fluvial corridor inventoried along the altitude-slope line (modified from $[12])$.

\section{AREA OF STUDY}

According to the classification using the system A of the Annex II of the FWD, the Adige River Basin corresponds to the Ecoregion 4 (Alps) for the northern portion of its mountain basin and the Ecoregion 3 (Italy, Corse, and Malts) for its down-mountain and plain portion. The typology size based on the catchment area is "very large" $\left(11,954 \mathrm{~km}^{2}\right)$, but "large" if we consider only the subbasin of the Ecoregion 4, Alps $\left(2,722 \mathrm{~km}^{2}\right)$. The Altitude typology is "high" $>800 \mathrm{~m}$, "middlealtitude" $200-800 \mathrm{~m}$, "lowland" $<200 \mathrm{~m}$ a.s.l., as we can show from the altitude profile of the river course (Fig. 2). The geological composition is siliceous in the higher portion of the basin and calcareous in the rest. The 11 sample areas tested in the Model of the Analysis and Environmental Evaluation also differ according to the classification using System B in the following aspects: distance from river source, energy of flow (function of flow and slope), mean water width (from few meters in the stretch 01 to more than $200 \mathrm{~m}$ in the stretch 11), mean water depth, mean water slope, form and shape of main riverbed (natural, embanked, channel, suspended), river discharge (flow) category, valley shape, mean substratum composition (from cobbles to sand-mud), and fallings. The landscape features differ as well as regarding the soil use of the corridor and the riparian areas and the water uses, including power, irrigation, drinking use, free time, and fish life (Fig. 3).

\section{METHODS}

A variety of ecosystem compartments and attributes were evaluated (Table 1). Each analysis was applied within the time and space parameters required by the experimental method of the analysis itself. The translation of the results of the quantitative and functional analyses into five quality classes was achieved by a two-step evaluation that took into account the quality of the single variables or criteria considered as well as the overall quality. The intermediate evaluations put out the critical factors. 


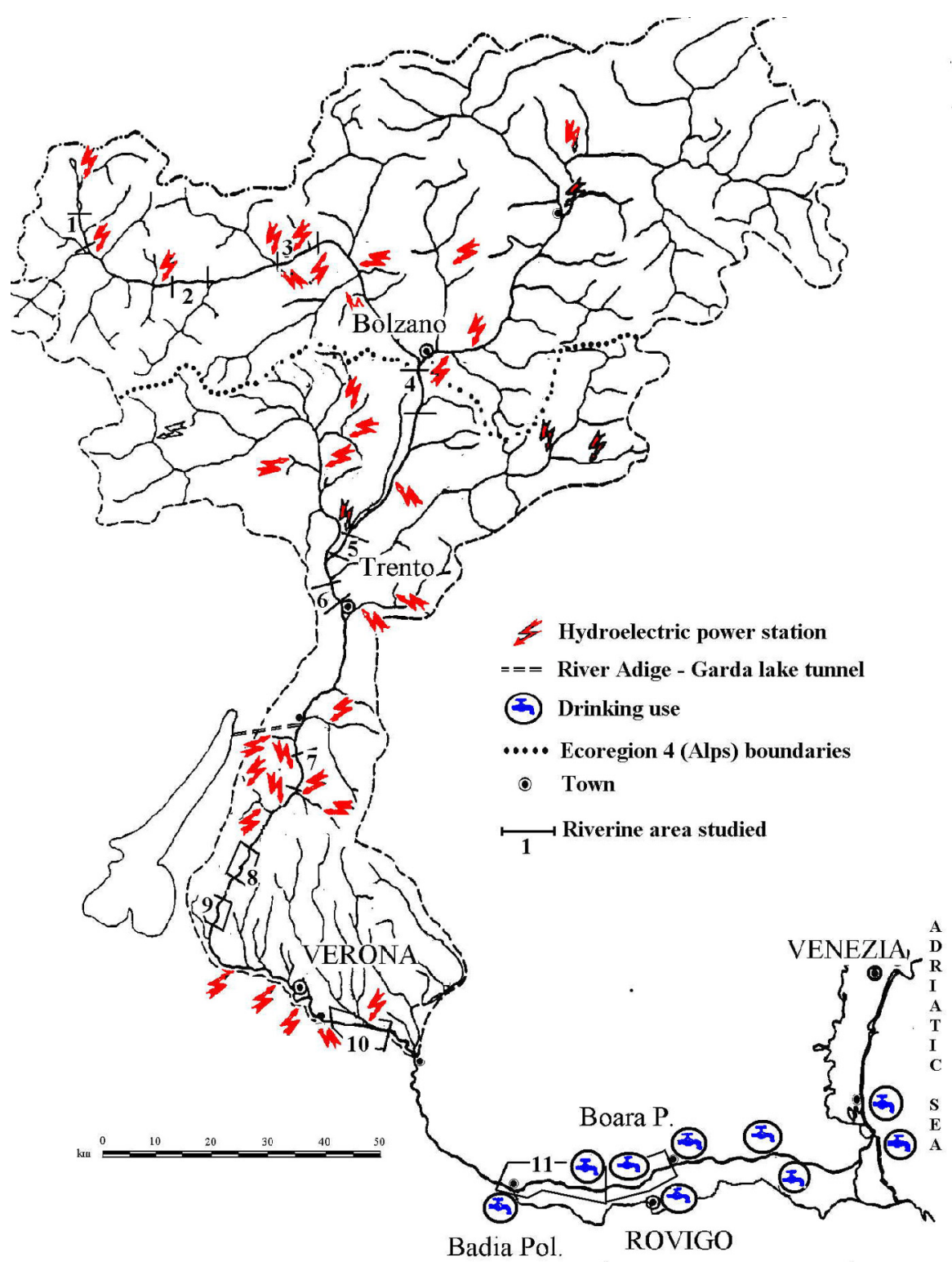

FIGURE 3. The Adige River Basin and the 11 areas of the fluvial corridor inventoried. Areas 8 through 11 are displayed in the square (modified from [13]).

\section{Assessment of the Landscape Quality of the Riparian Areas}

The landscape quality of the riparian areas was evaluated by the environmental landscape index (ELI)[14]. It evaluates the capacity for change of the investigated areas, which can be defined as the capacity of the territory to maintain, recover, and modify its character within a perspective of the safeguard of environment and the compatibility with human activities. The ELI uses a landscape analysis form built on purpose. This form is applied within the area of fluvial pertinence (inventory area), which is defined based on the geomorphologic features and human presence within the area itself, surveyed upon existing cartography, upon aerial photos, and onthe-spot investigation. A wide inventory area can even be divided into subareas[11,13,14]. The landscape analysis programme calculates the values of the index. The database is linked to the GIS database (see Table 2; Fig. 4). 
TABLE 1

List of the Analyses Achieved Divided According to the Ecosystem Compartments and Components

River Corridor
Borderlines of single
stretch of analysis,
Administrative Communal,
Administrative Regional
PRG Communal
Hydrogeological map
Geomorphological map
Geolithological map
Geopedological and
agronomical map
Cultivation use map
Lands agronomical
classification map
Actual cultivation map
Intensive and precious
cultivation map
Penalties in building
purposes map
Cultural goods map
Communal property lands
List
Austrian cadastre
Plan of State properties
Table for determining the
expropriation

\section{Banks - Riparian Areas}

Riparian areas

Landscape quality:

Environmental Landscape Index (ELI)

Hydro-morphological elements: Buffer strip potentiality - Buffer Strip Index (BSI)

Potentiality to support a high Biodiversity - Wild State Index (WSI)

Biological elements: Phytosociological analysis Natural value of the vegetation

Productivity of the tree vegetation: Salix alba, Alnus incana, Populus tremula

Productivity of the grass vegetation:

Phragmites australis,

Typhoides arundinacea

Bank invertebrate fauna

\section{Water Column, Bed, Interstitial Environment}

\author{
Chemical elements of surface water \\ Macrodescriptors level \\ Single uses: drinking, bathing, irrigation, \\ Salminid water, Ciprinid water \\ Loads of nutrients \\ Chemical Elements of groundwater: \\ Hydrochemical quality of the deep waters
}

Biological elements

-Phyto and zooplankton:

structure and composition, abundance, biovolume, biomass, chlorophyll a, loads of animals and inorganic matter, saprobic quality, diversity indices

-Macrozoobenthos:

Biological quality (EBI, Extended Biotic Index), Ephemeroptera, Plecoptera,

Trichoptera (EPT) taxa, quantitative structure and composition, density, biomass, functional feeding groups, diversity indices

-Recolonisation of artificial substrata: diversity, density, biomass, EPT taxa, functional feeding groups, trend of the process

—Litter processing (natural leaf packs): diversity and quantity of leaves, diversity and

quantity of macrozoobenthos

- Interstitial fauna:

structure and composition, diversity

Hydro-morphological elements: granulometry of substratum, lotic environmental quality

Modified from [13].

\section{Assessment of the Banks Quality}

The quality of the banks was assessed by the wild state index (WSI) and the buffer strip index (BSI)[13,14]. The BSI provides an indirect measure of the bank's capacity for filtering, metabolising, and bioaccumulating the nutrients and the pollutants conveyed by the river during the periods of high flow or percolating into the river from the surrounding territory 
TABLE 2

Extension of the Sampling Stretches from 8 to 11 Reported as an Example and Number of IA and Samples

\begin{tabular}{|c|c|c|c|c|c|c|}
\hline \multirow{3}{*}{$\begin{array}{l}\text { Stretch } \\
\text { No. }\end{array}$} & \multirow{3}{*}{$\begin{array}{l}\text { Extension km } \\
\text { Distance } \\
\text { from } \\
\text { Source }\end{array}$} & \multicolumn{3}{|c|}{ Riparian Areas } & \multirow{2}{*}{\multicolumn{2}{|c|}{ Banks }} \\
\hline & & \multirow{2}{*}{$\begin{array}{l}\text { ELI No. } \\
\text { IA }\end{array}$} & \multirow{2}{*}{$\begin{array}{l}\text { Phytosocio- } \\
\text { logical } \\
\text { Sampling } \\
\text { No. }\end{array}$} & \multirow{2}{*}{$\begin{array}{l}\text { Productivity of } \\
\text { Vegetation } \\
\text { Salix alba, Thyphoides } \\
\text { arundinacea, No. of } \\
\text { Samplings }\end{array}$} & & \\
\hline & & & & & BSI & WSI \\
\hline 8 & $209.9-219.6$ & 25 & 16 & 2 sites $\times 6$ months & 41 & 41 \\
\hline 9 & $224.1-237.5$ & 26 & 0 & & 16 & 16 \\
\hline 10 & $271.2-294.0$ & 36 & 10 & 2 sites $\times 6$ months & 47 & 47 \\
\hline 11 & $326.2-346.7$ & 30 & 30 & 2 sites $\times 6$ months & 29 & 29 \\
\hline
\end{tabular}

The WSI reflects the potentiality of the area to support a high level of biodiversity. Both indices survey an inventory area (IA) of the bank that measures $100 \times 100 \mathrm{~m}$ by a unique inventory sheet. The programme Banks 5.00 calculates the value and quality class of BSI and WSI. The IAs were located along the course of the river using the proportional stratified sampling method. Their number has also been increased in the fluvial stretches where the ecological analyses of the bed and the water column were carried out. Of the IA, $40 \%$ are included in the wider IA of the ELI (Table 2; Fig. 4).

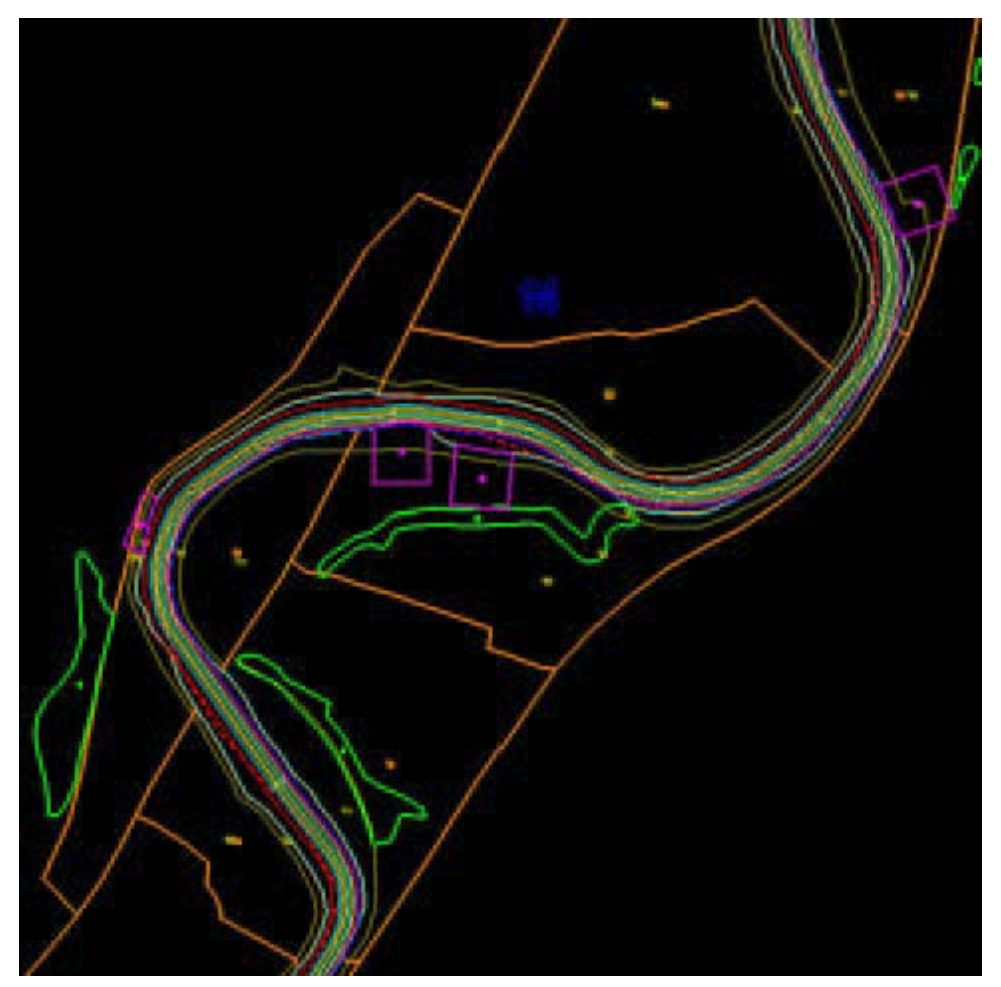

FIGURE 4: The GIS example; the areas of the river corridor analysed by the ELI are brown; the areas of botanical interest are green; the IA of the banks analysed by the BSI and WSI are yellow magenta. The river classes for the monitoring of the water quality according to Italian law: ecological state, macrodescriptors level, biological quality, drinkable use, bathing, Salmonid and Cyprinid suitability, irrigation[10, modified; 15$]$. 


\section{Quality of the Vegetation of the Riparian Areas and Fluvial Corridor}

Phytosociological samplings of the riparian vegetation (Table 2) and the following 68 samplings of fluvial corridor vegetation were located according to the interpretation of aerial photos for: (1) the natural state and value of the vegetation, (2) the fluvial corridor planning, and (3) the extrapolation of productivity measures. Of the phytosociological samples, $80 \%$ were carried out in the same IA assessed for the banks quality.

The translation into five quality classes was achieved according to the following parameters: structure, vegetation typology matching the soil characteristics, percentage of presence of native species.

\section{Quality of the Productivity of the Riparian Vegetation}

The primary production of Salix alba L. (riparian woods in middle and lower course) was taken into account within stretches 8, 10, and 11. Alnus incana (L.) Moench and Populus tremula L. (mixed riparian wood in higher course) were considered in stretch 2. The aboveground biomass of trees was evaluated with two complementary approaches: the biomass and the average increment of the trunk were measured by means of standard Schneider dendro-auxometric method applied to all individual trees in a $400-\mathrm{m}^{2}$ plot in each site; the biomass of branches was calculated according to an allometric model[16] as well as their increment[17]. Several linear regressions between the weight of branches (dependent variable) and diameter of the trunk (independent variable) were calculated on sample individual trees of $S$. alba representative of different diametric classes. The total biomass is the sum of biomasses of the trunk and branches.

The primary production of herbaceous riparian communities was measured in four sampling stretches within the areas near those already examined for their tree production. Phragmites australis (Cav.) Trin. community was taken into account in the higher course (stretch 2), and Typhoides arundinacea (L.) Moench communities in the medium and lower courses (stretches 8, 10, and 11). Samplings were carried out monthly. Each sampling phase consisted of cutting the aboveground plant biomass in ten $0.1225-\mathrm{m}^{2}$ randomly selected plots. Green biomass was kept in an incubator at $105^{\circ} \mathrm{C}$ up to constant weight. Eventually dry weight was measured and primary production calculated according to Groenondijk[18].

To translate the quantitative results into five quality classes the following criteria were adopted:

1. The results of production studies, with particular reference to the age structure of woody communities;

2. The morphological characteristics of the river course (regular or suspended riverbed);

3. The duration of contact between herbaceous vegetation and water from river and/or water table; and

4. The extension of the communities represented in the vegetation map.

\section{Quality of Plankton, Water Column, Sediments in the Lowland Course of the Adige River}

Twelve series of samplings of phytoplankton and zooplankton were collected on three stations $(11 \mathrm{a}-\mathrm{c})$ : the first two corresponded to the initial and final sample stretch $11(\mathrm{~km} 331.116-$ $346.750)$. In 11c ( $\mathrm{km} \mathrm{357.800)}$ the measures of the flow is recorded in continuum (Table 3$)$.

Because the number of the sampling stations was too small, a rigid range could not be assigned to variables in the assessment of quality classes. The translation of quantitative results into five quality classes, more suitable for biomonitoring, was carried out by a double-entry table. 
TABLE 3

Sampling of the Biological, Physical - Chemical Elements in the Lowland Course of the Adige River

\begin{tabular}{|c|c|c|c|c|c|c|}
\hline \multirow{2}{*}{$\begin{array}{l}\text { No. } \\
\text { Stretch }\end{array}$} & \multirow{2}{*}{$\begin{array}{l}\text { Element } \\
\text { Plankton }\end{array}$} & \multicolumn{5}{|c|}{ Samplings } \\
\hline & & No. in Space & Frequency & Volume & Depth (m) & Methods \\
\hline $11 a-c$ & Phytoplankton & $\begin{array}{l}1 \times \text { every single } \\
\text { transect }\end{array}$ & $\begin{array}{l}A(1 \mathrm{~h}) \mathrm{B} \times 12 \\
\text { months }\end{array}$ & 51 & $0.10-0.30$ & Bottle graduate \\
\hline $11 a-c$ & Zooplankton & $\begin{array}{l}3 \times \text { every single } \\
\text { transept }\end{array}$ & $\times 12$ months & 50 I total & $0.10-0.50$ & Patalas modified \\
\hline $11 a-c$ & Water & $\begin{array}{l}3 \times \text { every single } \\
\text { transect }\end{array}$ & 15 day range & 51 & $0-0.20$ & Bottle graduate \\
\hline $11 a-c$ & Sediment & $5 \times$ every station & $1 \times$ season & $20 \times 20 \mathrm{~cm}$ & $0-0.10$ & Grab \\
\hline
\end{tabular}

\section{Biological Elements}

Phytoplankton

Zooplankton

Chemical physical elements

Hydrological elements

\section{Laboratory Analysis}

Subsample, fixative, count, identification, biovolume, chlorophyll a

Copepoda, Cladocera gathered by $45-\mu$ nets, Rotifera $25 \mu$, biomass (dry weight) of Rotifera, Diversity Indices, Saprobic Index, Cluster Analysis, Load organic and inorganic quantities

Chemical - physical, microbiological parameters of water; $\mathrm{N}$ and $P$ loads in water and sediments

Continuous flow measurement

\section{References}

$64,65,66,67,68,69$, $70,71,72,73,74$

$15,21,22,23,30,75$ $76,77,78,79$

80,81

15

The qualitative score of excellent, medium, or poor for every variable evaluated-variety, $\%$ plankton species, plankton species dominance, density, biovolume, Diversity index $\left(\mathrm{H}^{\prime}\right)$, Maximum Diversity (H max), Eveness index (J), Dominance index (D), Saprobic index value, Rotifera loads, inorganic and organic loads, chlorophyll a, conductivity, $\mathrm{pH}$, cloudiness, sedimentary solids, total dry weight, total suspended solids, stationary residuum, volatile solidswas indicated according to correspondence to the literature data related to the season and the hydrological variability[15,19,20,21,22,23,24,25,26,27,28,29,30,31,32,33,34,35].

The following criteria were taken into account when the self-purifying capacity of the lowland course of the Adige River was classified according to quality class: the increase, decrease, and constancy of the loads of $\mathrm{N}$ and $\mathrm{P}$ flowing through the three stations; and the quantity of nutrients released by the sediments.

\section{Quality of Interstitial Hyporheic Environment of the Rhythral Watercourse}

Inquiries on the hydrochemical characteristics of the interstitial and surface waters, on the interstitial hyporheical fauna, and on the sediment granulometry were carried out within stretches 8 to 10 (Table 4 ).

The interstitial hyporheical fauna was sampled seasonally within stretches 2 to 10 (five pseudoduplicate for each area), by the Bou-Rouch method at a depth of 30-40 cm and filtering by a $25-\mu \mathrm{m}$ net the 301 of sample water.

The translation of quantitative results into five quality classes was carried out by a doubleentry table. The qualitative score of excellent, medium, or poor for the single variables evaluated variety, percentage of interstitial species, interstitial density/total density, number of 
TABLE 4

List of the Elements Evaluated in the Interstitial Environment in the Stretches 8, 9, 10

Element
Hydrochemical elements of
surface water
Hydrochemical elements of
interstitial water
Interstitial sediment granulometry
Interstitial hyporheic fauna

\section{Element}

Hydrochemical elements of surface water interstitial water Interstitial hyporheic fauna

\begin{tabular}{lccl} 
Sample Dimensions & \multicolumn{2}{c}{ No. of Sampling } & References \\
\cline { 2 - 3 } & In Space & In Time & \\
Point & 10 & 4 & 80,81 \\
$\begin{array}{l}\text { Point (30- to 40-cm depth) } \\
\text { peristaltic pump }\end{array}$ & 10 & 4 & $46,80,81$ \\
$\begin{array}{l}\text { (40- } \times \text { 40- } \times \text { 40-cm depth) } \\
\text { Point (30- to 40-cm depth) }\end{array}$ & 2 & 2 & 15 \\
& 15 & 4 & 82,83
\end{tabular}

Ephemeroptera, Plecoptera, Trichoptera (EPT) taxa, ratio of EPT taxa to total taxa, ratio of EPT density to total density, H', H max, J, D, Saprobic index — was indicated in conformity with the literature data and the results of the historical series of 1972-73 on the course of the Adige River[36,37,38,39,40,41,42,43,44,45,46,47,48,49,50,51,52,53,54,55,56,57,58,59].

Interstitial hyporheic water samples and surface samples were gathered at each interstitial hyporheical fauna sampling. The following parameters were analysed: temperature, conductivity, total suspended solids, total hardness, total alkalinity, nutrients (ammonia, nitrate, nitrite, total nitrogen, ortophosphate, total phosphate), biochemical oxygen demand, chemical oxygen demand, oxygen dissolved, total organic carbon, and some anions and cations (calcium, magnesium, sodium, potassium, chloride, sulfate). Moreover, the abundance of total coliform, fecal coliform, fecal streptococci and Salmonella was tested.

The evaluation of the quality of the interstitial hyporheic waters was carried out according to Italian Decreto Legislativo 258/2000 concerning underground waters. The evaluation of the quality of the surface waters was made according to the DL 258/2000[60] of the evaluation of the macrodescriptors pollution level.

The granulometry data on a low flow period after a medium flow period and after a long period of low flow were translated into quality classes by means of a reference range based on both the class I as proposed by Angelier[61] for gravel and granules up to $2 \mathrm{~mm}$ (45 to $75 \%$ ) and the V class for a rhythral stretch with fine compact sand without interstices.

\section{Morphohydrological Quality of the Riverbed}

The granulometry of the riverbed substratum was inventoried seasonally. It was translated into quality classes according to the correspondence of the mineral grain size dominance to the river type expected by the River Continuum Concept. The evaluation of the morphohydrologic characteristics of the lotic environment was carried out according to the scheme reported in Table 5 , by adopting the following criteria:

1. The sampling of the substratum must be carried out during a period of lower flow (both regulated and natural).

2. The homogeneous stretch of bed of the sampling must be at least $40 \mathrm{~m}$ long.

3. The velocity of the flow must be measured along an entire section of the bed and possibly within the different morphological types: pool, run, and riffle.

4. "Shadowed" indicates the percentage of wet bed that is in contact with the banks, and that falls in the shadow cone induced by the riparian vegetation.

5. The reference substrata in the rhythral stretches include stones, cobbles, rough gravel, medium gravel, fine gravel, sand, mud, rough and fine organic particles. 


\title{
TABLE 5
}

The Lotic Environmental Quality Class as Determined by the Mean of the Single Classes

$\begin{array}{lllll}\text { Class } & \text { Hydrological Variations } & \begin{array}{l}\text { No. of Substrata- } \\ \text { Extension }\end{array} & \begin{array}{l}\text { Diversity of } \\ \text { Velocity Flow }\end{array} & \% \text { Shadow } \\ \text { I } & \text { Natural } & \text { 7 Types-similar } & \text { Excellent } & >50 \\ \text { II } & \text { Regulated, nonrelevant } & \text { 5 Types-similar } & \text { Good } & =50>30 \\ \text { III } & \text { Regulated, modify the low flood } & \text { 3 Types-different } & \text { Medium } & =30>10 \\ \text { IV } & \text { Regulated, weekly } & \text { 2 Types-dominate 1 } & \text { Scarce } & =10 \\ \text { V } & \text { Regulated, daily } & \text { 1 Type } & \text { Laminar } & \text { Absent }\end{array}$

The reference substrata in the potamal stretches includes floating macrophytes, rooted macrophytes, rough sand, fine sand, mud, rough and fine organic particles.

\section{Quality of Macrozoobenthos}

The inquiries on macrozoobenthos were particularly articulated and took into consideration the structure of the community (EBI)[62,63], the quantitative aspects of the taxonomic and functional feeding groups, the main function of the leaf litter breakdown (natural and artificial), and the capacity for colonising inorganic substrata.

Table 6 reports the methods and the time and space dimension of the qualitative and quantitative analyses carried out on the macrobenthic communities of the Adige River in stretches 8 to 11 . See Table 7 for a translation of the qualitative sample data on the macrobenthic fauna into a functional evaluation, which is more useful for the survey and control monitoring.

\section{TABLE 6}

Inquiries on Macrobenthos Referring to the Method Used, Number of Duplicate Samples, and Laboratory Analyses

Inquiry

Qualitative structure and composition of benthos Density and biomass of benthos

Leaf litter breakdown processing

Leaf litter breakdown processing

Colonisation

\section{Analysis}

Qualitative benthos

Density benthos

Litter - processing

Litter - processing

Colonisation

Environment
Substratum
Substratum
Natural leaf packs
A. glutinosa leaf- bags
Artificial substrata

\section{Environment}

Natural leaf packs

Artificial substrata

\section{Laboratory Analysis}

Identification taxa, density for $\mathrm{m}^{2}$

Functional feeding groups, density for $\mathrm{m}^{2}$

Dry weight biomass for $\mathrm{m}^{2}$

$\mathrm{H}^{\prime}, \mathrm{H}$ max; J, D indices calculation
Tools

Ref.

Net

Surber

Natural leaf packs

Artificial leaf - bags of Alnus glutinosa

Boxes

63

84

85,86

$87,88,89$

90,91

$\begin{aligned} & \text { No. of Duplicates } \\
& \text { In space }\end{aligned}$
\begin{tabular}{ll} 
In time \\
\hline 1 & 4 \\
$2-3$ & 4 \\
5 & 3 \\
5 & 6 \\
5 & 6
\end{tabular}

$20 \mathrm{~cm}$

\author{
References \\ $92,93,94$ \\ 95 \\ HETO Drywinner G-55 at the Biol. Lab. Laives (BZ)[96] \\ $26,76,77$
}


TABLE 7

Translation of the Qualitative Results on the Macrobenthic Fauna into Quality Classes

$\begin{array}{lcccc}\text { Quality Class } & \text { Variety (No. of Taxa) } & \text { EPT Taxa/Total Taxa } & \text { EBI } & \text { Score } \\ \text { I } & 16 & 44 & >10 & \text { Excellent } \\ \text { II } & 11-15 & 44-36 & 8-9 & \text { Good } \\ \text { III } & 6-10 & 36-30 & 6-7 & \text { Medium } \\ \text { IV } & 2-5 & 30-20 & 4-5 & \text { Scarce } \\ \text { V } & 0-1 & <20 & <4 & \text { Very bad }\end{array}$

TABLE 8

Method for Translating the Quantity Data for Macrobenthos into Functional Evaluations: Step 1

$\begin{array}{cccccc}\begin{array}{c}\text { Quality } \\ \text { Class }\end{array} & \begin{array}{c}\text { Variety (No. of } \\ \text { Taxa) }\end{array} & \text { Density }\left(\mathbf{n} / \mathbf{m}^{2}\right) & \begin{array}{c}\text { \% Density EPT } \\ \text { taxa }\left(\mathbf{n} / \mathbf{m}^{2}\right)\end{array} & \begin{array}{c}\text { Biomass } \\ \left(\mathbf{m g} / \mathbf{m}^{2}\right)\end{array} & \begin{array}{c}\text { Contribution in } \\ \text { Biomass of Functional } \\ \text { Feeding Groups }\end{array} \\ \text { I } & >12 & >10.000 & >51 & >2.000 & \mathrm{dg}<60 \% \text { and } 5 \mathrm{gp} \\ \text { II } & 10 \text { to } 11 & 5.000-9.999 & 41-50 & 1.000-1.999 & \mathrm{dg} 61-70 \% \text { and } 5 \mathrm{gp} \\ \text { III } & 8 \text { to } 9 & 1.000-4.999 & 21-40 & 500-999 & \mathrm{dg} 71-80 \% \text { and } 5 \mathrm{gp} \\ \text { IV } & 5 \text { to } 7 & 500-999 & 10-20 & 100-499 & \mathrm{dg} 80-89 \% \text { and } / \mathrm{or} 4 \mathrm{gp} \\ \text { V } & <5 & <499 & <10 & <100 & \mathrm{dg}>90 \% \text { and } / \text { or } 3 \mathrm{gp}\end{array}$

\begin{tabular}{|c|c|c|c|c|}
\hline $\begin{array}{l}\text { Quality } \\
\text { Class }\end{array}$ & Diversity (H') & Homogeneity (H max) & J (H'/Hmax) & Richness (D) \\
\hline 1 & $4 \geq H^{\prime} \leq 5$ & $4 \geq \mathrm{H} \max \leq 5$ & $0.8 \geq \mathrm{J} \leq 1$ & $4 \geq D \leq 5$ \\
\hline II & $3 \geq \mathrm{H}^{\prime}<4$ & $3 \geq \mathrm{H} \max <4$ & & $3 \geq \mathrm{H}^{\prime}<4$ \\
\hline III & $2 \geq \mathrm{H}^{\prime}<3$ & $2 \geq \mathrm{H} \max <3$ & $0.6 \geq \mathrm{J}<0.8$ & $2 \geq \mathrm{H}^{\prime}<3$ \\
\hline IV & $1 \geq \mathrm{H}^{\prime}<2$ & $1 \geq \mathrm{H} \max <2$ & & $1 \geq \mathrm{H}^{\prime}<2$ \\
\hline $\mathrm{V}$ & $\mathrm{H}^{\prime}<1$ & $\mathrm{H} \max <1$ & $\mathrm{~J}<0.6$ & $\mathrm{H}^{\prime}<1$ \\
\hline
\end{tabular}

$\mathrm{dg}=$ percentage of the biomass of dominant groups compared to the total biomass.

$\mathrm{gp}=$ number of the functional feeding groups occurring in the sample.

TABLE 9

Method for Translating the Macrobenthos Quantity Data in Functional Evaluations: Step 2

$\begin{array}{cccc}\text { Quality Class } & \text { Score } \times \text { Analysis } & \text { Total Score } & \text { Quality } \\ \text { I } & 5 & 37-45 & \text { Excellent } \\ \text { II } & 4 & 28-36 & \text { Good } \\ \text { III } & 3 & 19-27 & \text { Medium } \\ \text { IV } & 2 & 10-18 & \text { Scarce } \\ \text { V } & 1 & 9 & \text { Very bad }\end{array}$

The procedures for translating the data, obtained by quantitative samplings of macrobenthos and by the analyses of the organic (natural leaf packs, Alnus glutinosa leaf bags) and inorganic substrata colonisation into five quality classes are the same in the first step (Table 8). When in the second step the overall quality class was defined, results from the following analyses were assessed: natural leaf packs, artificial leaf bags, inorganic substrata, and the trend of the process (Table 9, 10). 
TABLE 10

Method for Translating the Macrobenthos Quantity Data of the Natural Leaf Packs, Artificial Leaf Bags, and Inorganic Substrata in Functional Evaluations: Step 2

Quality Class

$\begin{array}{cc}\text { I } & 37-45 \\ \text { II } & 28-36 \\ \text { III } & 19-27 \\ \text { IV } & 10-18 \\ \text { V } & 9\end{array}$

Quality

Excellent

Good

Medium

Scarce

Very bad
Trend of the Process

$$
\begin{gathered}
\mathrm{A}=\text { under expectation } \\
\mathrm{B}=\text { unexpected, for natural progression }
\end{gathered}
$$

$\mathrm{C}=$ very unusual for time progression

\section{Implementation of Results}

According to the analysis and environmental evaluation model defined and applied on the 11 stretches of the Adige River and the fluvial corridor, the biological and ecological results were implemented and inserted in the GIS of the Adige Basin Authority, by the following four themes:

1. Classification of the surface water quality as requested by the Italian norms for each use;

2. Definition of the ecological status as requested by the DL $258 / 2000$;

3. Evaluation of the ecological status according to the Elements of the Annex V of the FWD $60 / 2000$, using also the results of functional evaluations;

4. Elaboration of the Quality, Degradation and Risk Map.

\section{RESULTS AND DISCUSSION}

\section{Classification of the Surface Water Quality as Requested by Italian Norms}

In sample stretches 8 to 11 , swimming, salmon breeding, and irrigation are completely forbidden (see Table 11). These areas can be used for drinking only after treatment through high costs of plant and management. Stretches 8 to 10 can host Ciprinida only; stretch 11 is unsuitable.

\section{Definition of the Ecological Status}

As shown in Table 12, the ecological status of the Adige River (as defined by the method proposed by DL 258/2000) corresponds to the lowest level among the classes of the macrodescriptor level of pollution (MLP) and of biological quality (BQ) as defined by EBI. In addition, it shows a general degradation.

TABLE 11

Classification of Superficial Waters According to Use

\begin{tabular}{lllllcc} 
Stretch & Drinking & Salmonida & Ciprinida & \multicolumn{1}{c}{ Irrigation } & \multicolumn{1}{c}{ Microbiology } \\
8 & A3 & Unsuitable & Suitable & Unsuitable (contaminated by & Chemistry & Swimming \\
9 & A3 & Unsuitable & Suitable & $\begin{array}{l}\text { Salmonella) } \\
\text { Unsuitable (contaminated by }\end{array}$ & I/II & No \\
10 & A3 & Unsuitable & Suitable & $\begin{array}{l}\text { Salmonella) } \\
\text { Unsuitable (contaminated by }\end{array}$ & I/II & No \\
11 & A3 & Unsuitable & Unsuitable & $\begin{array}{l}\text { Salmonella) } \\
\text { Unsuitable on not cooked } \\
\text { vegetables }\end{array}$ & II & No
\end{tabular}

A3 = appropriate physical and chemical treatment, including affination and desinfection, is needed to make the water fit to drink. 
TABLE 12

Ecological Status Classification of Stretches 8 to 11

Stretch
8
9
10
11

$\begin{array}{cc}\text { Water } & \text { MLP } \\ \text { Samples } & \text { II } \\ 8 & \text { II } \\ 8 & \text { II } \\ 8 & \text { II }\end{array}$

Benthos
Samples
20
20
12
12

BQ
III/II
III
IV
IV/III - V

Ecological Status
III/II
III
IV
IV/III - V

This monitoring is useful for identifying the quality objectives that need to be achieved, but it does not offer the knowledge necessary to determine the possible structure and management interventions necessary to reach those objectives. It does not offer planners the information they need to identify effective and coherent interventions and make appropriate decisions.

\section{Assessing the Ecological Status}

The biological, ecological, and landscape analyses previewed by the model of analysis and environmental evaluation proposed for and applied on the 11 stretches of the Adige River allowed an assessment of their ecological status. See Fig. 5 for a synthetic comparison of the landscape quality and the natural state and value of vegetation of the riparian areas, as well as the potentiality of the banks to sustain a high level of biodiversity and filter and bioaccumulate nutrients and pollutants within the stretches 8 to 11 . The primary production of woody riparian vegetation is synthesized in Tables 13 and 14, and the production trend of herbaceous vegetation is shown in Table 15 and Fig. 6. Tables 16 and 17 report the synthesis of the functional evaluations on interstitial hyporheic and benthic fauna, on plankton, and on self-purifying capacity (only for stretch 11), for $30 \mathrm{~km} \mathrm{ca}$. of the lowland watercourse.

\section{Fluvial Corridor Quality of the Adige River in Sample Stretches}

The landscape quality of the riparian areas is mostly medium. There are a few good quality areas of class I. Human pressure in stretch 9 is deep, as shown by the prevailing presence of class III, IV, and V IA. The result is confirmed by the absence of areas with vegetation that is typical from a phytosociological point of view. The discordance shown in Fig. 5 between the low percentage of IA in class I and II and the high percentage of vegetation relevance in class II within stretches 8,10 , and 11 is caused by the different surface sampled in the two methods. Both confirm the presence of areas in which the natural value of the vegetation is medium or presents the typical typology (class I).

In these areas the tree production of Salix alba and grass production of Typhoides arundinacea shows a class II quality. The first result is confirmed by the diametric structure of the tree communities and wood production results (Table 13, 14). The highest values were surveyed despite the differences in the structure of the populations. The highest wood biomass occurs in stretch 8 where the oldest individuals of $S$. alba occur. The highest growth values are found in stretch 10 , where the tree population is dominated by young individuals.

The wood in stretch 2, although having a young-tree dominating structure, shows low growth values due to bad soil composition (abundant gravel fraction) if compared with the other three sites in which sand-silt soil textures prevail. (These data on stretch 2 is not reported in this paper.)

The herbaceous riparian communities also show the highest values in these stretches, even if few differences occur that show the influence of the flow regimen on their primary productivity. As shown in Table 15 and in Fig. 6, two seasonal patterns of biomass occur: in stretches 8 and 10 


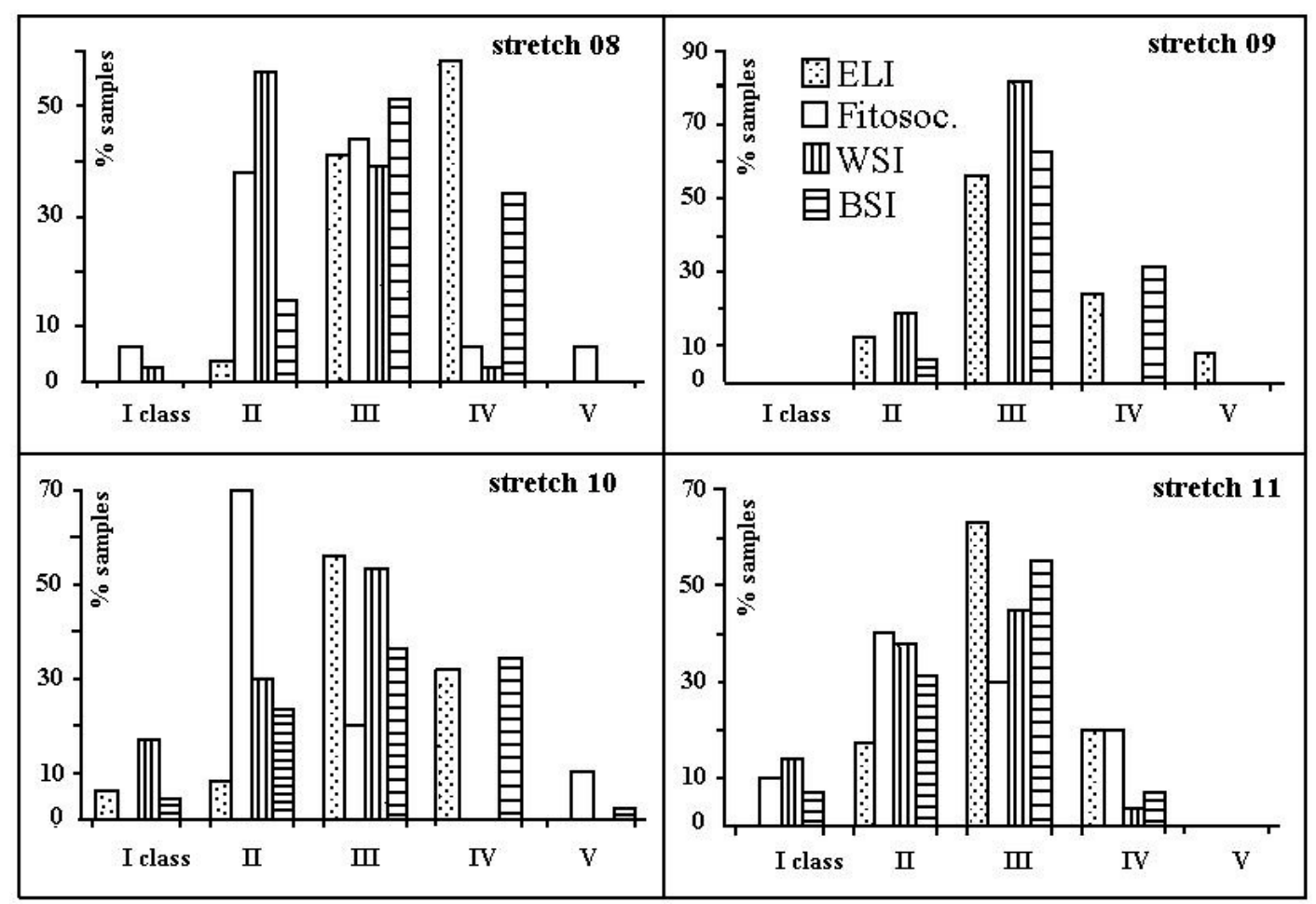

FIGURE 5. Trends of percentage of the riparian areas, riparian vegetation, and banks wild state - buffer quality class.

TABLE 13

Biomass of Trees and Their Yearly Growth in a Hectare

$\begin{array}{ccccccc}\text { Stretch } & \begin{array}{c}\text { Biomass of } \\ \text { Trunk (t/ha) }\end{array} & \begin{array}{c}\text { Branches } \\ \text { Biomass } \\ \text { (t/ha) }\end{array} & \begin{array}{c}\text { Total } \\ \text { Biomass } \\ \text { (t/ha) }\end{array} & \begin{array}{c}\text { Yearly Growth } \\ \text { of Trunk (t/ha } \\ \text { year) }\end{array} & \begin{array}{c}\text { Yearly Growth } \\ \text { of Branches } \\ \text { (t/ha year) }\end{array} & \begin{array}{c}\text { Total Yearly } \\ \text { Growth (t/ha } \\ \text { year) }\end{array} \\ 2 & 18.46 & 1.28 & 19.74 & 6.06 & & \\ 8 & 93.54 & 6.59 & 100.12 & 15.13 & 0.22 & 6.28 \\ 10 & 48.80 & 2.79 & 51.59 & 18.74 & 0.46 & 15.80 \\ 11 & 84.36 & 4.42 & 88.77 & 13.65 & 0.61 & 14.20 \\ & & & & & & \end{array}$

TABLE 14

Distribution of Individual Trees within Diametric Classes

Diametric Classes (cm)

\begin{tabular}{llcccccc}
\cline { 2 - 7 } Stretch & Species & $\mathbf{5} \mathbf{5}$ & $\mathbf{> 7} \mathbf{1 0}$ & $\mathbf{> 1 0} \leq \mathbf{1 5}$ & $\mathbf{> 1 5} \leq \mathbf{2 0}$ & $\mathbf{2 0} \leq \mathbf{2 5}$ & $\mathbf{> 2 5}$ \\
11 & Salix alba L. & 50 & 42 & 41 & 8 & - & - \\
10 & S. alba L. & 55 & 59 & 18 & 2 & - & - \\
08 & S. alba L. & 24 & & 20 & 24 & 4 & 1 \\
02 & All & 46 & 19 & 13 & - & - & - \\
& Populus tremula L. & 16 & 13 & 8 & - & - & - \\
& Robinia pseudacacia L. & 8 & 2 & 4 & - & - & - \\
& Alnus incana (L.) Moench & 13 & 3 & - & - & - & - \\
& Betula pendula Roth & 5 & 1 & - & - & - & - \\
& Prunus avium L. & 3 & - & 1 & - & - & -
\end{tabular}


TABLE 15

Net Production of Herbaceous Vegetation

$\begin{array}{cc}\text { Stretch } & \begin{array}{c}\text { Yearly Total Net } \\ \text { Production }\left(\mathbf{g}^{-2} \mathbf{m}^{-2}\right)\end{array} \\ 2 & 932.33 \\ 8 & 979.66 \\ 10 & 1168.73 \\ 11 & 1263.35\end{array}$
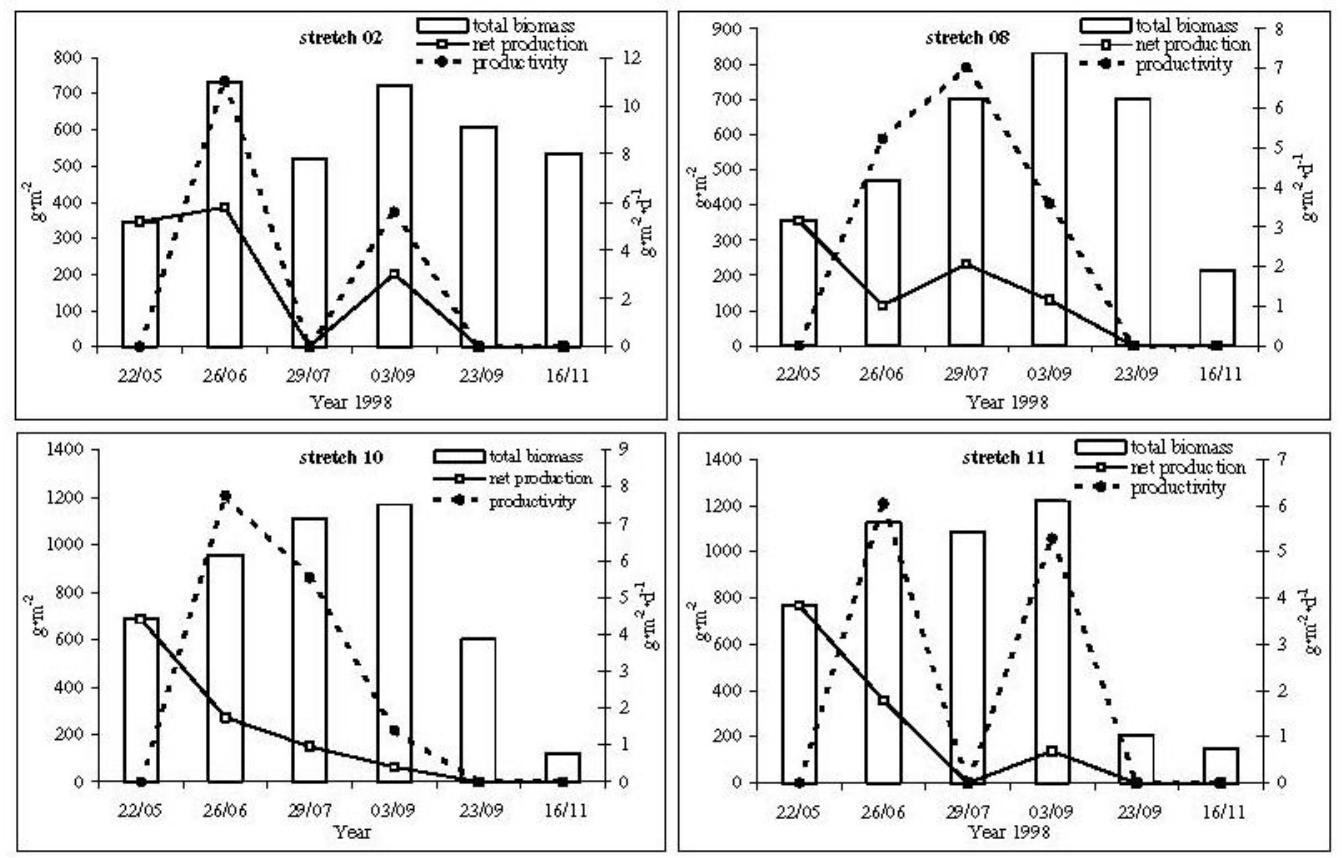

FIGURE 6. Primary production trends for herbaceous vegetation in the four sampling sites.

the total biomass reaches the highest value in summer; in stretches 2 and 11 two maximum total biomass values are present in early and late summer while a minimum is shown in the third sampling cycle. In the first two sites the herbaceous vegetation is submerged during floods but is protected from the destructive impact of river flows. On the contrary, in the other two sites the herbaceous vegetation is submerged during floods, but is also affected by partial destruction of aboveground parts. Both dominating species react successfully to this crisis by being deeply rooted in the soil, although their stems are prostrate after floods: Phragmites australis resumes its vertical stem growth, while $T$. arundinacea produces new shoots from the stem nodes. Production values of $T$. arundinacea communities are generally greater in the lower course of the Adige River if compared to alpine course. P. australis shows higher values in the highest site, but its production values are quite small if compared to those measured in lacustrine reedbeds or on the banks of slow-flow watercourses where little or no disturbance occurs.

The banks show a potentiality to support a high biodiversity, good-medium (classes II to III) (Fig. 5) where a strip of vegetation, even very small, stays between the river and the agrarian cultures. The wild state quality increases in the banks of the riparian areas where ELI and the natural value of the vegetation show class I quality. The capacity to filter and bioaccumulate nutrients and pollutants conveyed downstream during floods and/or coming from the territory is almost absent; in some stretches the banks could favour increased pollutant concentrations. The IA of class I represent very small banks stretches. 
TABLE 16

Loads of Rotifera and Organic Matter in the Water Column, and Quality

$\begin{array}{lccc} & \text { km } \mathbf{3 3 1} & \mathbf{k m} \mathbf{3 4 6} & \mathbf{k m} \mathbf{3 4 7} \\ \text { Rotifera dry weight } \mathbf{k g} / \text { day/year } & 21 & 23 & 26 \\ \text { Organic matter dry weight t/day/year } & 47 & 51 & 50 \\ \text { Plankton } & & \text { III/IV class of quality } & \\ \text { Self-purifying capacity } & & \text { IV class of quality }\end{array}$

TABLE 17

Quality Class of Components, Compartments, and Functional Processes

\begin{tabular}{|c|c|c|c|c|c|c|c|c|c|}
\hline $\begin{array}{l}\text { Sample } \\
\text { Stretch }\end{array}$ & $\begin{array}{l}\text { Inter- } \\
\text { stitial } \\
\text { Water }\end{array}$ & $\begin{array}{l}\text { Inter- } \\
\text { stitial } \\
\text { Fauna }\end{array}$ & $\begin{array}{l}\text { Interstitial } \\
\text { Substratum } \\
\text { Granulometry }\end{array}$ & $\begin{array}{l}\text { Lotic } \\
\text { Environ- } \\
\text { ment }\end{array}$ & $\begin{array}{l}\text { Macro- } \\
\text { benthos } \\
\text { (Quantity) }\end{array}$ & $\begin{array}{l}\text { Natural } \\
\text { Leaves } \\
\text { Breakdown }\end{array}$ & $\begin{array}{l}\text { Leaf Bags } \\
\text { Break- } \\
\text { down }\end{array}$ & $\begin{array}{l}\text { Leaf Bag } \\
\text { Colonisa- } \\
\text { tion }\end{array}$ & $\begin{array}{l}\text { Colonisation } \\
\text { of Artificial } \\
\text { Substrata }\end{array}$ \\
\hline 08 & II & III & III & III & III to II & & $A$ to $A$ & C to IV & A IV to III \\
\hline 09 & II & III & III & II & III to IV & III to III & $A$ to $A$ & D to IV & A III \\
\hline 09 & II & III & & IV & III to IV & & & & \\
\hline 09 & II & III & & III & III to IV & & & & \\
\hline 10 & & IV & & IV & & & & & \\
\hline 10 & & & & IV & III to IV & & & & \\
\hline 11 & & & & IV/III & III to IV & & $E$ to $D$ & B to II & \\
\hline 11 & & & & IV & III to IV & & & & \\
\hline
\end{tabular}

\section{Water Column in the Plain Stretch of the Adige River}

The absence or/and reduction of the banks' buffer capacity are confirmed by specific research on the nutrient loads conveyed into the water column and occurring in the sediments along the $30 \mathrm{~km}$ of the plain stretch corresponding in the first $20 \mathrm{~km}$ to the stretch 11 . The evaluation of the selfpurifying capacity of the river achieved according to these data shows a class IV. The regulation of the banks and the flow are major factors in preventing the development of a plankton community (phytoplankton and zooplankton) that can contribute to the water column's selfpurification (class III/IV). Other results confirm this fact: phytoplankton presents only one peak in the winter months during the continual low flow regimen even if nutrients never limit its development. Chlorophyll and pheophytin, and zooplankton and Rotifera show a similar trend. Rotifera is the dominant group as in the zooplankton of the Po River, but the percentage of planktonic species and the loads of Rotifera as dry weight are very low (see Table 16).

\section{Riverbed, Interstitial Environment, and Macrobenthos}

The synthesis of the functional evaluations on the interstitial hyporheic and macrobenthic fauna shown in Table 17 is useful for understanding the level of the degradation already shown by the EBI. Not only are the structure and the composition of macrobenthos compromised, but also the biological processes. The morphological conditions of the riverbed, often bearing periodic and drastic excavations of bed and banks, and the flow trend-which is very regulated, with weekly and even daily variation caused by power management-have modified the macrobenthos as well as the interstitial hyporheic fauna and the granulometric structure of the superficial and deep bed: the riverbed became bold and waterproof, with a significant loss of microhabitats for colonisation. 

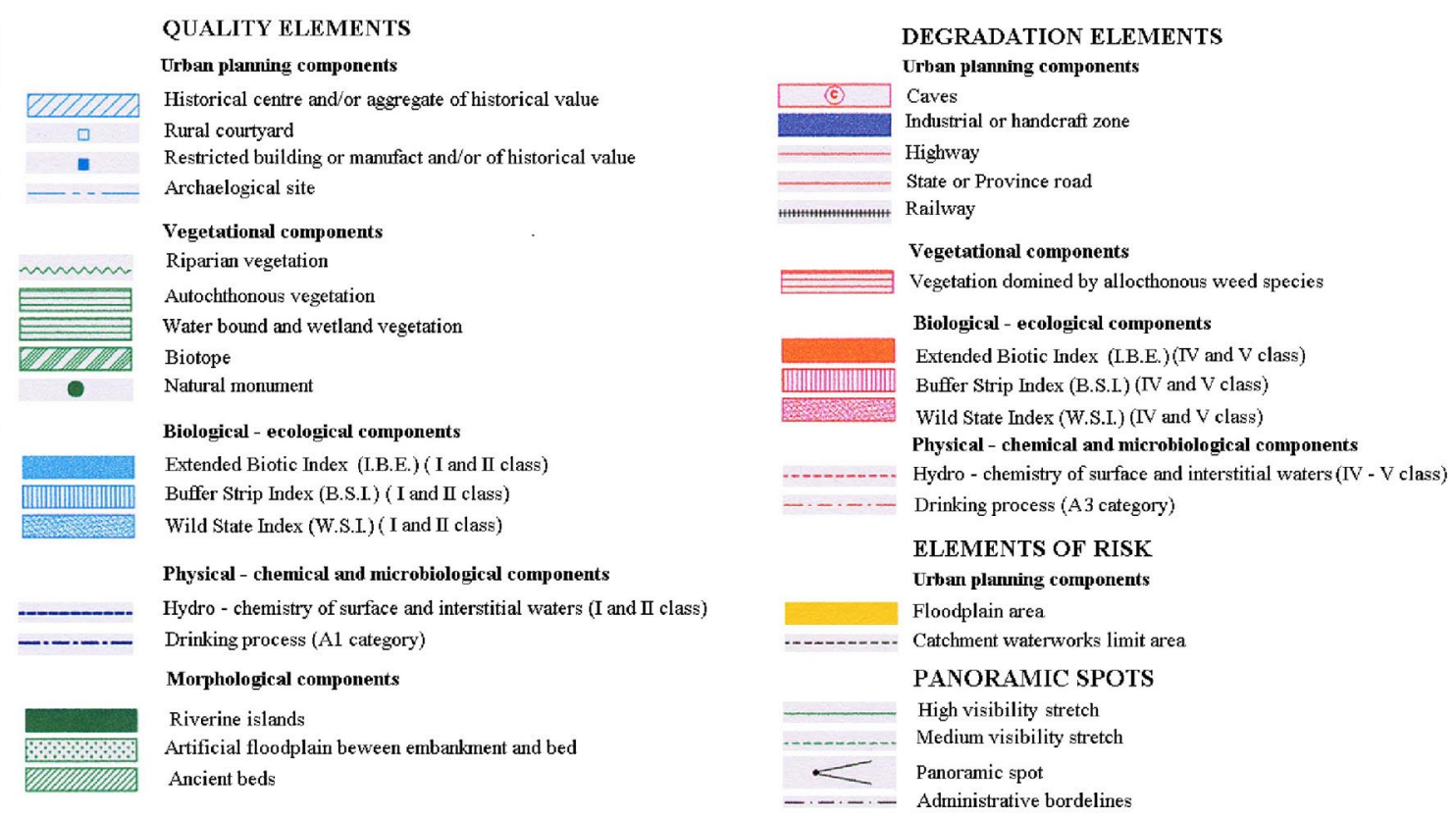

FIGURE 7. Map of quality, degradation, and risks (modified from [10]).

\section{Quality, Degradation, and Risks Map}

All the results of the qualitative and quantitative monitoring are introduced in the database of GIS. These data together with the human impact elements of the fluvial corridors shown in Table 1 are elaborated according to a five-dimensional view into the planning and management of the Adige River Basin. The thematic map showing quality, degradation, and risks presented in Figs. 7,8 , and 9 is a example of the higher precision achieved when the following are taken into account: the more affected components of the ecosystem or those to be safeguarded; the potential fruition of the different stretches of the river supported by the integration of the biologicalecological data with those deriving from the planning process[11].

\section{CONCLUSIONS}

Monitoring waters to classify them for each single use and to define their ecological status is useful for identifying water quality objectives to be achieved. However, monitoring methods do not offer enough data to show the possible structural and management interventions necessary to reach the fixed quality objectives. The procedures that this paper propose, which use multiarticulated ecological indices and functional evaluations, provide a synthetic, representative view of the structural and functional aspects of the river ecosystem that planners can easily interpret. These innovative procedures evaluate the biological, ecological, and hydromorphologic data of the river, the banks, and the riparian areas, along with the human impact elements of the fluvial corridors. They provide much more precise information on the interventions and actions needed to improve the quality of the watercourses in its complex and to obtain fixed quality objectives. 


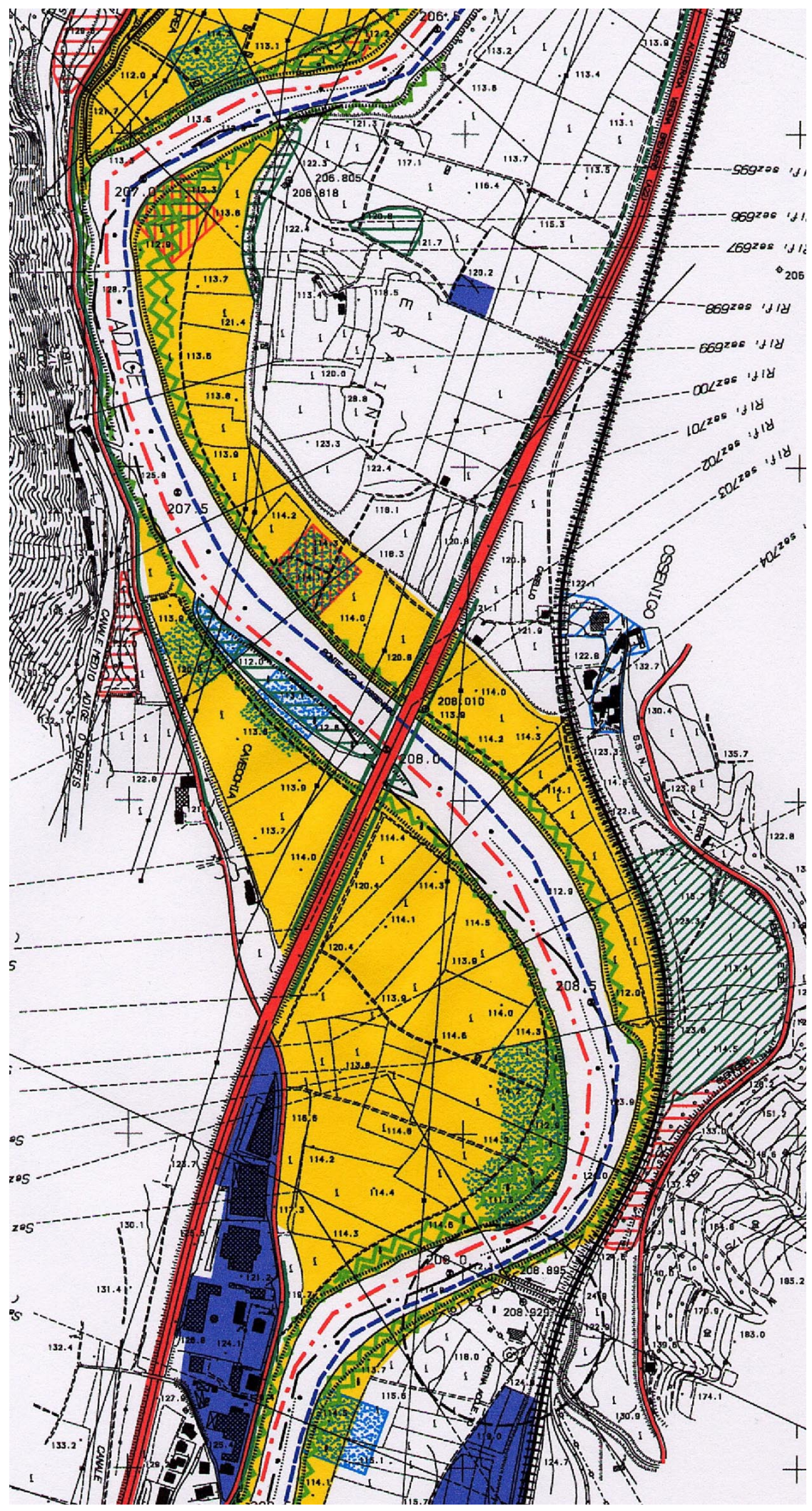

FIGURE 8. Map of quality, degradation, and risks for stretch 8 (modified from [10]). 


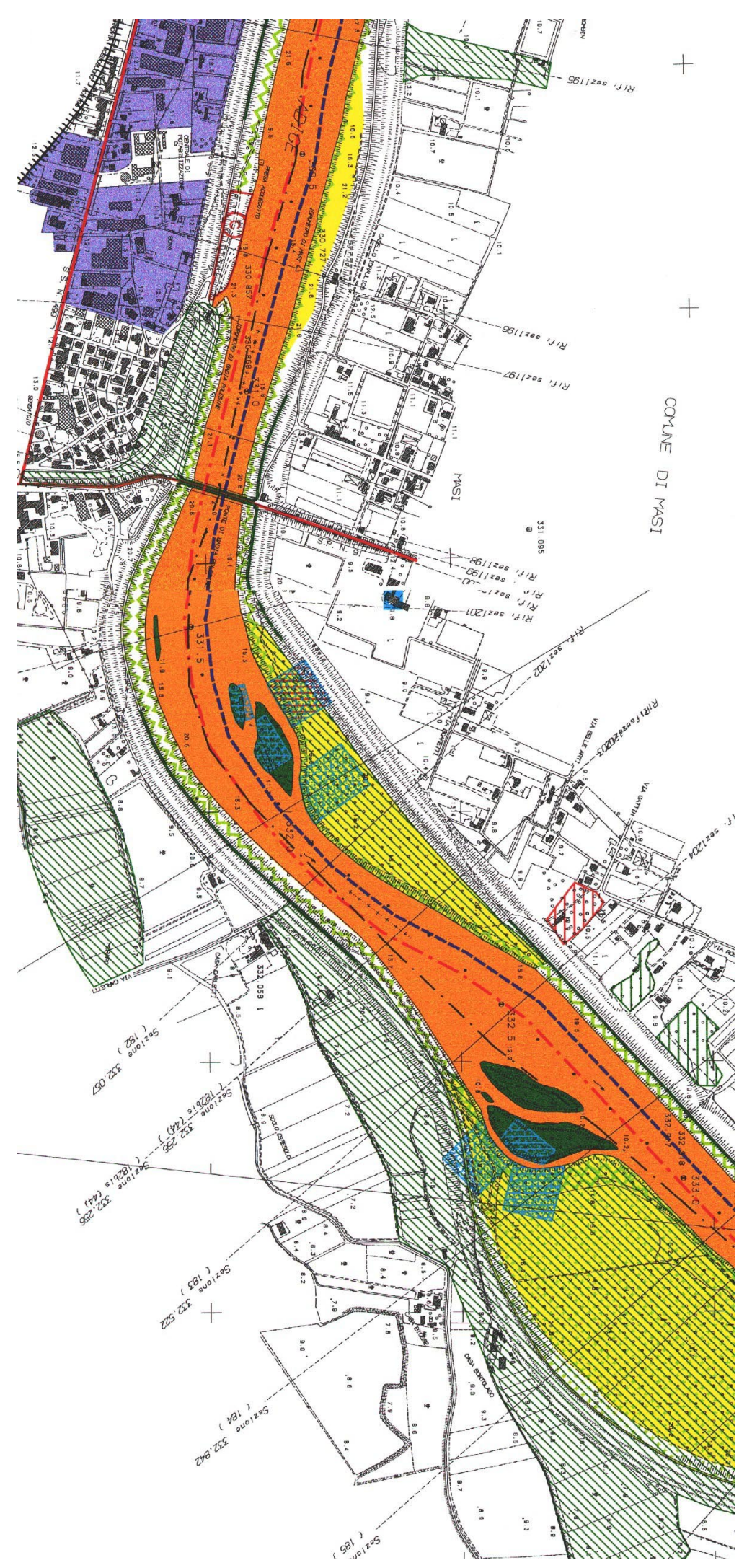

FIGURE 9. Map of quality, degradation, and risks for stretch 11 . 


\section{ACKNOWLEDGEMENTS}

This paper relies on research and studies that were financed by the National Basin Authority of the Adige River to support the layout of the Adige Basin Management Plan.

\section{REFERENCES}

1. Statzner, R.B. and Higler, B. (1985) Question and comments on the river continuum concept. Can. J. Fish. Aquat. Sci. 42, 1038-1044.

2. Vannote, R.L., Minshall, G.W., Cummins, K.W., Sedell, J.R., and Cushing, C.E. (1980) The river continuum concept. Can. J. Fish. Aquat. Sci. 37, 130-137.

3. Newbold, J.D., Elwood, J.W., O'Neill, R.W., and Webster, V.W. (1981) Measuring nutrient spiralling in streams. Can. J. Fish. Aquat. Sci. 38, 860-863.

4. Naiman, R.J., Decamps, H., Pastor, J., and Johnston, C.A. (1988) The potential importance of boundaries to fluvial ecosystem. J. N. Am. Benthol. Soc. 7, 289-306.

5. Naiman, R.J. and Decamps, H., Eds. (1990) The Ecology and Management of Aquatic-Terrestrial Ecotones. Man and the Biosphere Series, 4. The Parthenon Publishing Group, Carnforth, England.

6. Boon, P.J. (1992) Essential elements in the case for river conservation. In River Conservation and Management. Boon, P.J., Calow, P., and Petts, G.E., Eds. John Wiley \& Sons, New York. pp. 11-34.

7. Hynes, H.B.N. (1975) The stream and its valley. Verh. Int. Verein. Limnol. 19, 1-15.

8. Ward, J.V. (1989) The four-dimensional nature of lotic ecosystem. J. N. Am. Benthol. Soc. 8, 2-8.

9. European Commission (2000) E.C. Directive 60/2000 23.10.2000. Framework for Community Action in the Field of Water Policy. L.327.

10. Braioni, M.G., Braioni, A., Girelli, L., Masonale, M., Salmoiraghi, G., and Francescon, M. (2001) A model of environmental analysis and evaluation for the planning and management of the catchment basin: the Adige River corridor as case of study.Terr@A in brief 5(1), 14-23.

11. Campeol, G., Braioni, A., Girelli, L., and Masconale, M. (2000) Utilizzi pianificatori delle analisi biologico ecologiche in alcune aree campione fluviali dell'Adige. Autorità di Bacino Nazionale del fiume Adige. Final Report. DAEST - IUAV.

12. Miliani, L. (1937) Le piene dei fiumi veneti. L’Adige. R. Acc. Naz. Lincei, Ed. Le Monnier Firenze 7(1), 100.

13. Braioni, M.G., Bracco, F., Cisotto, P., Ghirelli, L., Villani, M.C., Braioni, A., Girelli, L., Masconale, M., Campeol, G., and Salmoiraghi, G. (2000) The biological-ecological and environmental landscape indices and procedures in the planning and sustainable management of the riverine areas: the case of the study of the river Dese and Adige River. In New Trends in Water and Environmental Engineering for Safety and Life. Maione, U., Majone Lehto, B. and Monti, R., Eds. Balkema, Rotterdam. pp. 97-110.

14. Braioni, M.G., De Franceschi, P., Braioni, A., Campeol, G., Caloi, S., Grandis, N., Pontiroli, A., and Ravanello, P. (2001) New environmental indices for assessing bank quality in the restoration and the sustainable management of a river. Ecohydrol. Hydrobiol. 1(1-2), 133-154.

15. Braioni, M.G., Ed. (2001). Studi e Ricerche finalizzati alla conoscenza integrata della qualità delle rive del fiume Adige: Final Report. Autorità di Bacino Nazionale del fiume Adige, Università di Padova Dipartimento di Biologia, Università di Bologna - Dipartimento di Biologia Evoluzionistica, DAEST IUAV - Università di Venezia, Province Autonome di Trento e Bolzano, Regione Veneto.

16. Whittaker, R.H. and Marks, P.L. (1975) Methods of assessing terrestrial productivity. In Primary Productivity of the Biosphere. Ecological Studies 15. Lieth, H., Whittaker, R.H., Eds. Springer-Verlag, New York. pp. 55-118.

17. Newbold, P.J. (1967) Methods for Estimating the Primary Production of Forests. IBP Handbook 2. Blackwell, Oxford.

18. Groenendijk, A.M. (1984) Primary production of four dominant salt-marsh angiosperms in the SW Netherlands. Vegetatio 57, 143-152.

19. Admiraal, W., Breebaart, L., Tubbing, G.M.J., Van Zanten, B., De Ruijter Van Steveninck, E. D., and Bijkert, R. (1994) Seasonal variation in composition and production of planktonic communities in the lower River Rhine. Freshwater Biol. 32, 519-531.

20. Braioni, M.G. (1981) The drift of Rotifers in Adige River: preliminary communication. Boll. Zool. 48, 305-310.

21. Ferrari, I., Mazzoni, R., and Solazzi, A. (1987) Il popolamento del Fiume Po nell'estate 1985. Atti A.I.O.L. VII, 261-266.

22. Ferrari, I. and Mazzoni, R. (1989) Zooplankton in the Po River during the summer of 1985. Toxicol. Environ. Chem. 20/22, 39-48.

23. Ferrari, I., Farabegoli, A., and Mazzoni, R. (1989) Abundance and diversity of planktonic rotifers in the Po River. Hydrobiologia 186/187, 201-208. 
24. Galkovskaja, G.A. (1987) Planktonic rotifers and temperature. Hydrobiologia 147, 307-317.

25. Green, J. (1993) Diversity and dominance in planktonic rotifers. Hydrobiologia 255/256, 345-352.

26. Krebs, C.J. (1989) Ecological Methodology. Harper \& Row, New York.

27. Lair, N. and Reys-Marchant, P. (1997) The potamoplankton of the Middle Loire and the role of the "moving littoral" in downstream transfer of algae and rotifers. Hydrobiologia 356, 33-52.

28. Marneffe, Y., Descy, J.P., and Thome, J.P. (1996) The zooplankton of the lower river Meuse, Belgium: seasonal changes and impact of industrial and municipal discharges. Hydrobiologia 319, 1-13.

29. Pejler, B. and Berzins, B. (1993) On choice of substrate and habitat in bdelloid rotifers. Hydrobiologia 255/256, 333-338.

30. Podani, J. (1990) SYN - TAX IV. Computer Programs for Data Analysis in Ecology and Systematics on IBM - PC and Macintosh Computers. International Centre for Science and High Technology, Trieste, Italy.

31. Pourriot, R., Rougier, C., and Miquelis, A. (1997) Origin and development of river zooplankton: example of the Marne. Hydrobiologia 345, 143-148.

32. Reckendorfer, W., Keckeis, H., Winkler, G., and Schemer, F. (1999) Zooplancton abundance in the River Danube, Austria: the significance in a inshore retention. Freshwater Biol. 41, 583-591.

33. Snell, T.W. and Serra, M. (1998) Dynamics of natural rotifer population. Hydrobiologia 368, 29-35.

34. Sudzuki, M., Watanabe, K., Suzuki, K., and Narita, K. (1983) Occurrence of Rotifera in the field under natural and intentionally-changed conditions. Hydrobiologia 104, 341-347.

35. Viroux, L. (1997) Zooplankton development in two large lowland rivers, the Moselle (France) and the Meuse (Belgium), in 1993. J. Plankton Res. 19(11), 1743-1762.

36. Braioni, M.G. and Gottardi, M. (1976) I Rotiferi dell'Adige: confronto tra il popolamento interstiziale e quello bentico-perifitico. Boll. Mus. Civ. Stor. Nat. Verona 6, 187-219.

37. Braioni, M.G., Duzzin, B., Centurioni, M.C., Penna, G., Negroni, L., and Campaioli, S. (1981) L'ambiente interstiziale iporreico del fiume Brenta e la sua fauna. Boll. Mus. Civ. Stor. Nat. Verona 7, 235-274.

38. Carbonier, R. and Tremolieres, M. (1990) The Rhine Rift Valley groundwater-river interactions: evolution of their susceptibility to pollution. Regul. Rivers: Res. Manage. 5(5), 375-389.

39. Danielopol, D.L. and Marmonier, P. (1992) Aspects of research on groundwater along the Rhone, Rhine and Danube. Regul. Rivers: Res. Manage. 7(1), 5-16.

40. Ferrarese, U. and Sambugar, B. (1976) Ricerche sulla fauna interstiziale iporreica dell'Adige in relazione allo stato di inquinamento del fiume. Riv. Idrobiol. 15(I), 47-124.

41. Fraser, B.G. and Williams, D.D. (1998) Seasonal boundary dynamics of a groundwater/surface-water ecotone. Ecology 79(6), 2019-2031.

42. Gilbert, J., Dole-Olivier, M.J., Marmonier, P., and Vervier, P. (1990) Surface-groundwater ecotones. In The Ecology and Management of Aquatic-Terrestrial Ecotones. Man and Biosphere Series 4. Naiman, R.J. and Decamps, H., Eds. The Parthenon Publishing Group, Carnforth, England. pp. 199-222.

43. Gilbert, J., Danielopol, D.L., and Stanford, J.A. (1994) Groundwater Ecology. Academic Press, New York, 571 p.

44. Lowrance, R.R. (1992) Groundwater nitrate and denitrification in a coastal plain riparian forest. J. Environ. Qual. 21, 401-405.

45. Marmonier, P., Fontieille, D., Gilbert, J., and Vanek, V. (1995) Distribution of dissolved organic carbon and bacteria at the interface between the Rhone River and its alluvial aquifer. J. N. Am. Benthol. Soc.14(3), 382392.

46. Riolfatti, M. (1976) Ricerche sulla correlazione tra lo stato di inquinamento dell'acqua di corrente e dell'acqua interstiziale in un tratto del fiume Adige. Riv. Idrobiol. 15(I), 129-149.

47. Ruffo, S. (1961) Problemi relativi allo studio della fauna interstiziale iporreica. Boll. Zool. 28, $273-319$.

48. Schwoerbel, J. (1961) Uber die Lebensbedingungen und die Besiedlung des hyporheischen Lebensraumes. Arch. Hydrobiol. Suppl. 25, 182-214.

49. Stanford, J.A. and Ward, J.V. (1993) An ecosystem perspective of alluvial rivers: connectivity and the hyporheic corridor. J. N. Am. Benthol. Soc. 12 (1), 48-60.

50. Strayer, D.L., May, S.E., Nielsen, P., Wollheim, W., and Hausam, S. (1997) Oxygen, organic matter, and sediment granulometry as controls on hyporheic animal communities. Arch. Hydrobiol. 140, 131-144.

51. Tremolier, M., Roeck, U., Flein, J.P., Carbonier, R. (1994) The exchange process between river and groundwater on the central Alsace flood plain (Eastern France). II. The case of a river with functional flood plain. Hydrobiologia 273,19-63.

52. Triska, F.J., Duff, J.H., and Avanzino, R.J. (1993) Patterns of hydrological exchange and nutrient transformation in the hyporheic zone of a gravel-bottom stream: examining terrestrial-acquatic linkages. Freshwater Biol. 29, 259-274.

53. Valett, M.H., Hakenkamp, C.C., and Boulton, A.J. (1993) Perspectives on the hyporheic zone: integrating hydrology and biology. Introduction. J. N. Am. Benthol. Soc. 12(1), 40-43.

54. Vervier, P., Gilbert, J., Marmonier, P., and Dole-Olivier, M.-J. (1992) A perspective on the permeability of the surface freshwater-groundwater ecotone. J. N. Am. Benthol. Soc. 11(1), 93-102.

55. Weil, R.R., Weismiller, R.A., and Turner, R.S. (1990) Nitrate contamination of groundwater under irrigated Coastal Plain soil. J. Environ. Qual. 19, 441-448. 
56. White, D.S. (1993) Perspectives on defining and delineating hyporheic zones. J. N. Am. Benthol. Soc.12(1), 61-69.

57. Williams, D.D. (1993) Nutrient and flora vector dynamics at the hyporheic/groundwater interface and their effects on the interstitial fauna. Hydrobiologia 251, 185-198.

58. Wondzell, S.M. and Swanson F.J. (1996) Seasonal and storm dynamics of the hyporheic zone of a 4th order mountain stream. I. Hydrologic processes. J. N. Am. Benthol. Soc. 15(1), 3-19.

59. Wondzell, S.M. and Swanson, F.J. (1996) Seasonal and storm dynamics of the hyporheic zone of a 4th order mountain stream. II. Nitrogen cycling. J. N. Am. Benthol. Soc. 15(1), 20-34.

60. Decreto Legislativo 258 (2000) Disposizioni correttive e integrative del decreto legislativo 11 maggio 1999, n. 152, in materia di tutela delle acque dall'inquinamento, a norma dell'articolo 1, comma 4, della legge 24 aprile 1998, n. 128. G.U. 153/L, Roma.

61. Angelier, E. (1953) Recherches ecologiques et biogéographiques sur la faune des sables submergés. Arch. Zool. Exp. Gen. XC, 37-162.

62. Braioni, M.G. (1994) Faunistic research in a fluvial ecosystem study: the case of the river Adige. Boll. Zool. 61, 415-424.

63. Ghetti, P.F. (1997) Indice Biotico Esteso (I.B.E.). I macroinvertebrati nel controllo della qualità degli ambienti di acque corrente. Provincia Autonoma di Trento.

64. Anagnostidis, K. and Komárek, J. (1988) Modern approach to the classification system of Cyanophytes. 3Oscillatoriales. Arch. Hydrobiol. Suppl. 80, Algol. Stud. 50-53, 327-472.

65. Bourrelly, P. (1972) Les Algues d'eau douce. Initiation à la Systématique, I. Les Algues Vertes. N. Boubée and Cie, Paris.

66. Bourrelly, P. (1981) Les Algues d'eau douce. Initiation à la Systématique, II. Les Algues Jaunes et Brunes. N. Boubée and Cie, Paris.

67. Huber-Pestalozzi, G. and Fott., B. (1968) Cryptophyceae, Chloromonadophyceae, Dinophyceae. Das Phytoplankton des Sübwassers. Die Binnengewässer XVI, 3(2). E. Schweizerbart'sche Verlagsbuchhandlung, Stuttgart.

68. Huber-Pestalozzi, G. (1955) Euglenophyceen. Das Phytoplankton des Sübwassers. Die Binnengewässer XVI, 4. E. Schweizerbart'sche Verlagsbuchhandlung, Stuttgart.

69. Komárek, J. and Fott, B. (1983) Chlorophyceae (Grünalgen) Ordnung: Chlorococcales. Das Phytoplankton des Sübwassers. Die Binnengewässer XVI, 7(1). E. Schweizerbart'sche Verlagsbuchhandlung, Stuttgart.

70. Lorenzen, C.J. (1967) Determination of chlorophyll and pheo-pigments: spectrophotometric equations. Limnol. Oceanogr. 12, 343-346.

71. Lund, J.W.G., Kipling, C., and Le Cren, L.D. (1958) The inverted microscope method of estimating algal numbers and the statistical basis of estimations by counting. Hydrobiologia 11, 143-170.

72. Marker, A.F.H., Nusch, E.A., Ray, H., and Riemann, B (1980) The measurement of photosynthetic pigments in freshwaters and standardization of methods: conclusions and recommendations. Arch. Hydrobiol. 14, 91106.

73. Rott, E. (1981) Some results from phytoplankton counting intercalibrations. Schweiz. Z. Hydrol. 43, 34-62.

74. Saraceni, C. and Ruggiu, D. (1974) Techniques for sampling water and phytoplankton. In A Manual on Methods for Measuring Primary Production in Aquatic Environments. IBP Handbook 12. Vollenweider, R.A., Ed. Blackwell, Oxford. pp. 5-7.

75. Braioni, M.G. and Gelmini, D. (1983) Rotiferi Monogononti (Rotifera Monogononta). CNR. Guide Riconoscimento delle Specie Animali delle Acque Interne Italiane 23, 1-180.

76. Margalef, R. (1958) Information theory in ecology. Gen. Syst. 3, 37-71.

77. Shannon, C.E. and Weaver, W. (1963). The Mathematical Theory of Communication. University of Illinois Press, Urbana.

78. Sladecek, V. (1973) System of quality from the biological point of view. Arch. Hydrobiol. 7, 1-218.

79. Sladecek, V. (1983) Rotifers as indicators of water quality. Hydrobiologia 100, 169-201.

80. APHA, AWWA, and WPFC. (1992) Standard Methods for the Examination of Water and Wastewater. $16^{\text {th }}$ ed. American Public Health Association, Washington, D.C.

81. APHA, AWWA, and WEF. (1995) Standard Methods for the Examination of Water and Wastewater. $19^{\text {th }}$ ed. American Public Health Association, Washington, D.C.

82. Bou, C. (1974) Les méthodes de récolte dans les eaux souterraines interstitielle. Ann. Spéléol. 29(4), 611619.

83. Bou, C. and Rouch, R. (1967) Un nouveau champ de recherches sur la faune aquatique souterraine. $C$. $R$. Acad. Sci. 265, 369-370.

84. Rosenber, D.M. and Resh, V.H. (1992) Freshwater Biomonitoring and Benthic Macroinvertebrates. Chapman and Hall, London.

85. Baldy, V., Gessner, M.O., and Chauvet, E. (1995) Bacteria, fungi and the breakdown of litter in a large river. Oikos 74(1), 93-102.

86. Vought, L.B. and Lannerstad, M. (2000) The structure of the riparian ecotone and its implication for stream macroinvertebrate community. Proc. Int. Assoc. Theor. Appl. Limnol. 27, 1357-1360. 
87. Petersen, R.C. and Cummins, K.W. (1974) Leaf pack processing in a woodland stream. Freshwater Biol. 4, 343-368.

88. Hanson, B.J., Cummins, K.W., Barnes, J.R., and Carter, M.W. (1984) Leaf litter processing in aquatic system: a two variable model. Hydrobiologia 111, 21-29.

89. Cummins, K.W., Wilzbach, M.A., Gates, D.M., Perry, J.B., and Tagliaferro, W.B. (1989) Shredders and riparian vegetation. Bioscience 39(1), 24-30.

90. Shaw, D.W. and Minshall, G.W. (1980) Colonization of an introduced substrate by stream macroinvertebrates. Oikos 34, 259-271.

91. Williams, D.D. and Hynes, H.B.N. (1976) The recolonization mechanisms of stream benthos. Oikos 27, 265272.

92. Campaioli, S., Ghetti, P.F., Minelli, A., and Ruffo, S. (1994) Manuale per il riconoscimento dei macroinvertebrati delle acque dolci italiane. ARPA Trento, Eds. v. I, 1-356.

93. Campaioli, S., Ghetti, P.F., Minelli, A., and Ruffo, S. (1999) Manuale per il riconoscimento dei macroinvertebrati delle acque dolci italiane. ARPA Trento, Eds. v. II, 1-484.

94. C.N.R. (1977-1986) Guide per il riconoscimento delle specie animali delle acque interne italiane. Ruffo S. (ed.) Collana del Progetto Finalizzato "Promozione della Qualità dell'Ambiente", C.N.R., ROMA.

95. Merrit, R.W. and Cummins, C.W. (1988) An Introduction to the Aquatic Insects of North America. Kendall/Hunt Dubuque, Iowa.

96. Schwoerbel, J. (1993) Einf hrung in die Limnologie. Ed Gustav Fischer.

\section{This article should be referenced as follows:}

Braioni, M.G., Salmoiraghi, G., Bracco, F., Villani, M., Braioni, A., and Girelli, L. (2002) Functional evaluations in the monitoring of the river ecosystem processes: the Adige River as a case study. In Selected Papers on River Ecology and Ecosystem Communities and Function from the 2001 Symposium of European Freshwater Science. TheScientificWorldJOURNAL 2, 660-683.

\section{Handling Editor:}

Karl Havens, Principal Editor for Freshwater Systems — a domain of TheScientificWorldJOURNAL.

\section{BIOSKETCHES}

Maria Giovanna Braioni is Associate Professor of Zoology, Teacher of Conservation of the nature and its resources and of Ecology of Lotic Environments at the Department of Biology of the University of Padua. Her research interests include evaluation of the structure and function of macrobenthos, plankton, interstitial fauna, and of the quality and function of the riparian environment. Since 1990 she has been in charge of multi-disciplinary researches aimed at the rivers restoration.

Anna Braioni is an architect, associated to the National Institute of Urban Planning (INU). She was co-director of Major's thesis in Architecture and Applied Ecology. Her research interests include eco-compatible planning, projects of evaluation, rehabilitation and restoration of the Environment and the Landscape.

Loredana Girelli is an architect, with ressearch interests in the evaluation of the fluvial landscape.

Francesco Bracco is Associate Professor of Environmental and Applied Botany at the Faculty of Pharmacy of University of Pavia. He holds a Ph.D. in Systematics and Vegetal Ecology (Geobotany). Prof. Bracco' research interests include phytosociological study of the vegetation of Po Plain (N-Italy) with special reference to freshwater and fluvial habitats and planning and management of phytosociological databases for the vegetation of Italy (project LISY of Italian Association for Phytosociology).

Mariacristina Villani is a Post-doctoral fellow at Biology Department of Padova University. She holds a Ph.D. in Geobotany. Her research interests include phytosociological studies of fluvial habitats of NE Italy, production studies of riparian plant communities, floristic and vegetation analyses of Euganean Hills (NE of Italy), and monitoring control of forests. 
Gianpaolo Salmoiraghi has 26 years experience in river ecology. He has been senior scientist since1992 and Lecturer in Hydrobiology and Applied Ecology from 1992, at Biology Department of Bologna University. His major topics are use of biotic indexes in environmental monitoring, functional aspects of macrozoobenthos community, the effects caused by dams on macroinvertebrate communities, secondary production of invertebrate communities, and breakdown and colonization processes of natural and artificial leaf packs. In 1993 he was EU consultant (DG XI) for ANNEX I 92/43/CE. He is tutor and supervisor of Ph.D. students in ecology at the University of Bologna. Since 1993 he has beren in charge of hydrobiological studies for national and regional authorities. 

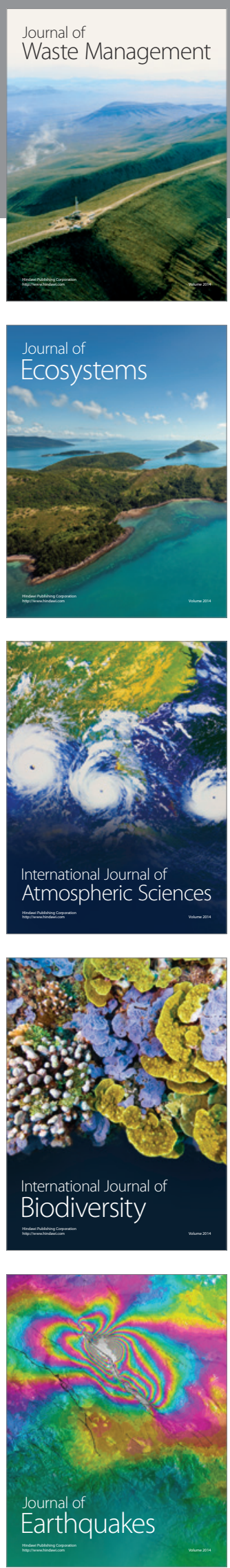
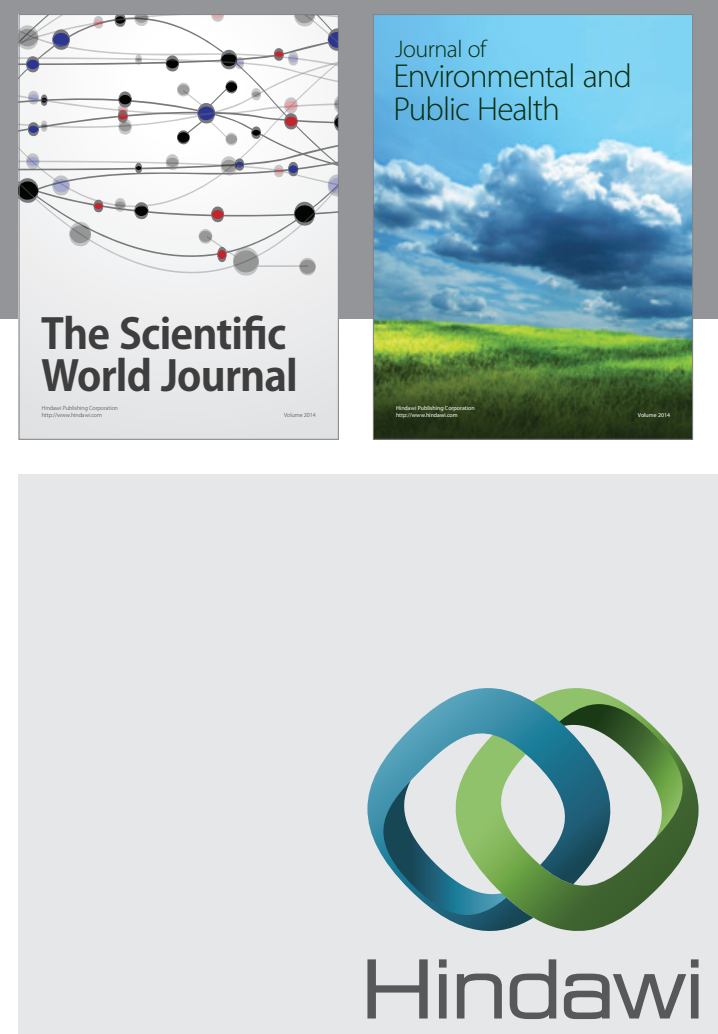

Submit your manuscripts at

http://www.hindawi.com
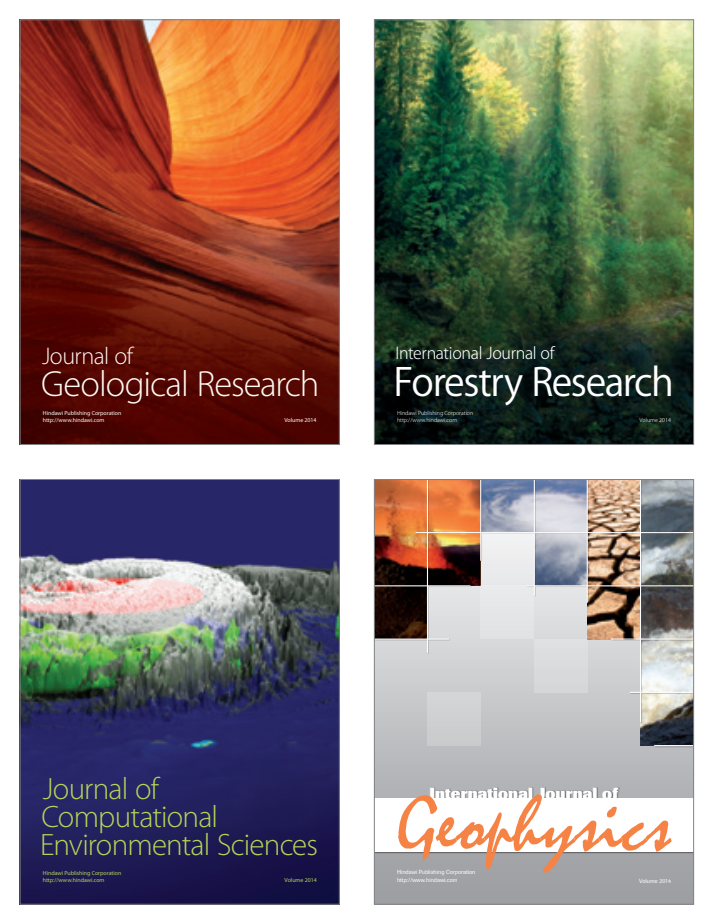
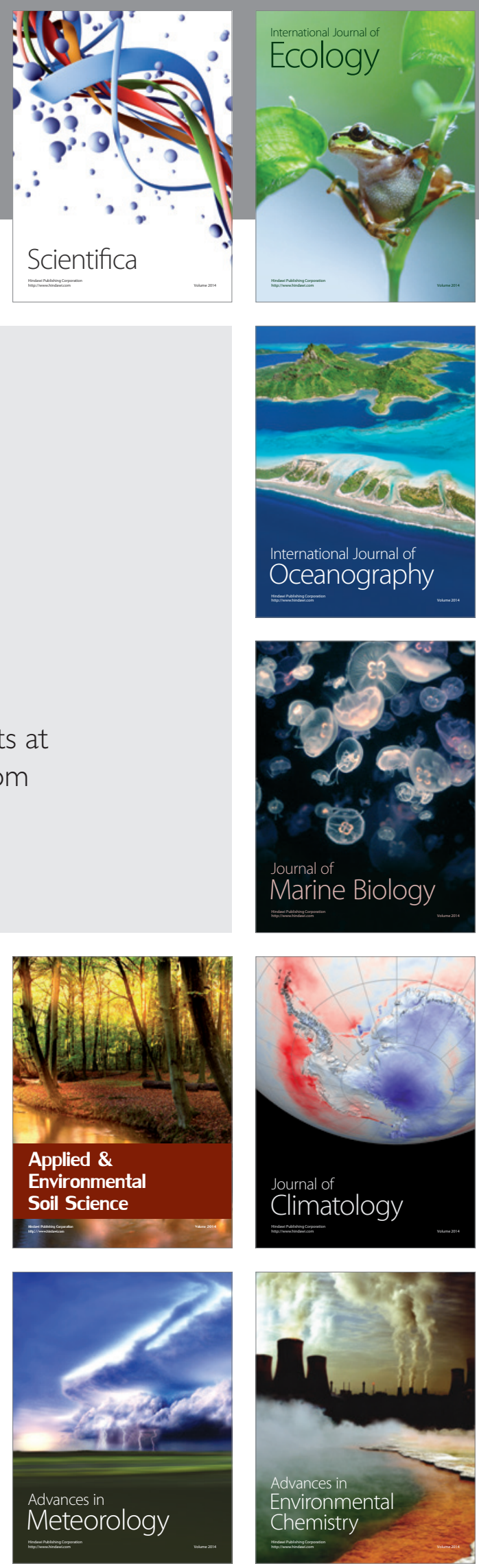